\title{
Challenge in the Discovery of New Drugs: Antimicrobial Peptides against WHO-List of Critical and High-Priority Bacteria
}

\author{
Cesar Augusto Roque-Borda 1(D), Patricia Bento da Silva ${ }^{2}$, Mosar Corrêa Rodrigues ${ }^{2}$, Ricardo Bentes Azevedo ${ }^{2}(\mathbb{D}$, \\ Leonardo Di Filippo $^{3}$, Jonatas L. Duarte ${ }^{3}$, Marlus Chorilli ${ }^{3}\left(\mathbb{D}\right.$, Eduardo Festozo Vicente ${ }^{4}(\mathbb{D})$ and \\ Fernando Rogério Pavan 1,*
}

Citation: Roque-Borda, C.A.; da Silva, P.B.; Rodrigues, M.C.; Azevedo, R.B.; Di Filippo, L.; Duarte, J.L.; Chorilli, M.; Festozo Vicente, E.; Pavan, F.R. Challenge in the Discovery of New Drugs: Antimicrobial Peptides against WHO-List of Critical and High-Priority Bacteria. Pharmaceutics 2021, 13, 773. https://doi.org/ 10.3390/pharmaceutics13060773

Academic Editor: Hwankyu Lee

Received: 16 April 2021

Accepted: 16 May 2021

Published: 21 May 2021

Publisher's Note: MDPI stays neutral with regard to jurisdictional claims in published maps and institutional affiliations.

Copyright: (c) 2021 by the authors. Licensee MDPI, Basel, Switzerland. This article is an open access article distributed under the terms and conditions of the Creative Commons Attribution (CC BY) license (https:/ / creativecommons.org/licenses/by/ $4.0 /)$.
1 Tuberculosis Research Laboratory, School of Pharmaceutical Sciences, São Paulo State University (UNESP), Araraquara 14800-903, Brazil; cesar.roque@unesp.br

2 Laboratory of Nanobiotechnology, Department of Genetics and Morphology, Institute of Biological Sciences, University of Brasilia, Brasilia 70910-900, Brazil; patrbent@gmail.com (P.B.d.S.); mosarcr@gmail.com (M.C.R.); razevedo@unb.br (R.B.A.)

3 Department of Drugs and Medicines, School of Pharmaceutical Sciences, São Paulo State University (UNESP), Araraquara 14800-903, Brazil; leonardo.filippo@unesp.br (L.D.F.); jl.duarte@unesp.br (J.L.D.); marlus.chorilli@unesp.br (M.C.)

4 School of Sciences and Engineering, São Paulo State University (UNESP), Tupã 17602-496, Brazil; eduardo.vicente@unesp.br

* Correspondence: fernando.pavan@unesp.br; Tel.: +55-16994305252

\begin{abstract}
Bacterial resistance has intensified in recent years due to the uncontrolled use of conventional drugs, and new bacterial strains with multiple resistance have been reported. This problem may be solved by using antimicrobial peptides (AMPs), which fulfill their bactericidal activity without developing much bacterial resistance. The rapid interaction between AMPs and the bacterial cell membrane means that the bacteria cannot easily develop resistance mechanisms. In addition, various drugs for clinical use have lost their effect as a conventional treatment; however, the synergistic effect of AMPs with these drugs would help to reactivate and enhance antimicrobial activity. Their efficiency against multi-resistant and extensively resistant bacteria has positioned them as promising molecules to replace or improve conventional drugs. In this review, we examined the importance of antimicrobial peptides and their successful activity against critical and high-priority bacteria published in the WHO list.
\end{abstract}

Keywords: AMPs; antibacterial activity; critical-priority bacteria; high-priority bacteria; MDR; XDR

\section{Introduction}

In recent decades, uncontrolled drug use has led to major public health, economic, and environmental problems. As a result, bacteria, as well as other microorganisms, have acquired or developed unfavorable resistance mechanisms toward conventional drugs [1]. The World Health Organization (WHO) has launched a priority list of bacteria that should be studied more rigorously, and all the bacteria on this list are resistant to various drugs [2]. Bacterial resistance is a global public health concern, and it becomes a serious problem when the line of resistance exceeds the inactivation of first-line drugs, which consequently leads to high mortality rates [3]. This problem arises when a bacterium begins to generate defense molecules or acquires resistance plasmids from other bacteria, which is why, in recent years, the use of drugs has been urgently restricted [4]. For this reason, in the search for new drugs, antimicrobial peptides (AMPs) have been highlighted.

AMPs are biomolecules produced as a defense mechanism of living beings, with excellent antibacterial, antifungal, and antiviral properties [5]. They are distinguished by their ability to greatly reduce the bacterial load to low concentrations and to generate a 
minimal response of bacterial resistance due to the rapid action with lipopolysaccharides (LPS) of the cell membrane [6]. This article reviews the growing number of studies that demonstrate the efficacy of antimicrobial peptides against major groups of dangerous bacteria, as potential new substituents for conventional drugs (Figure 1).

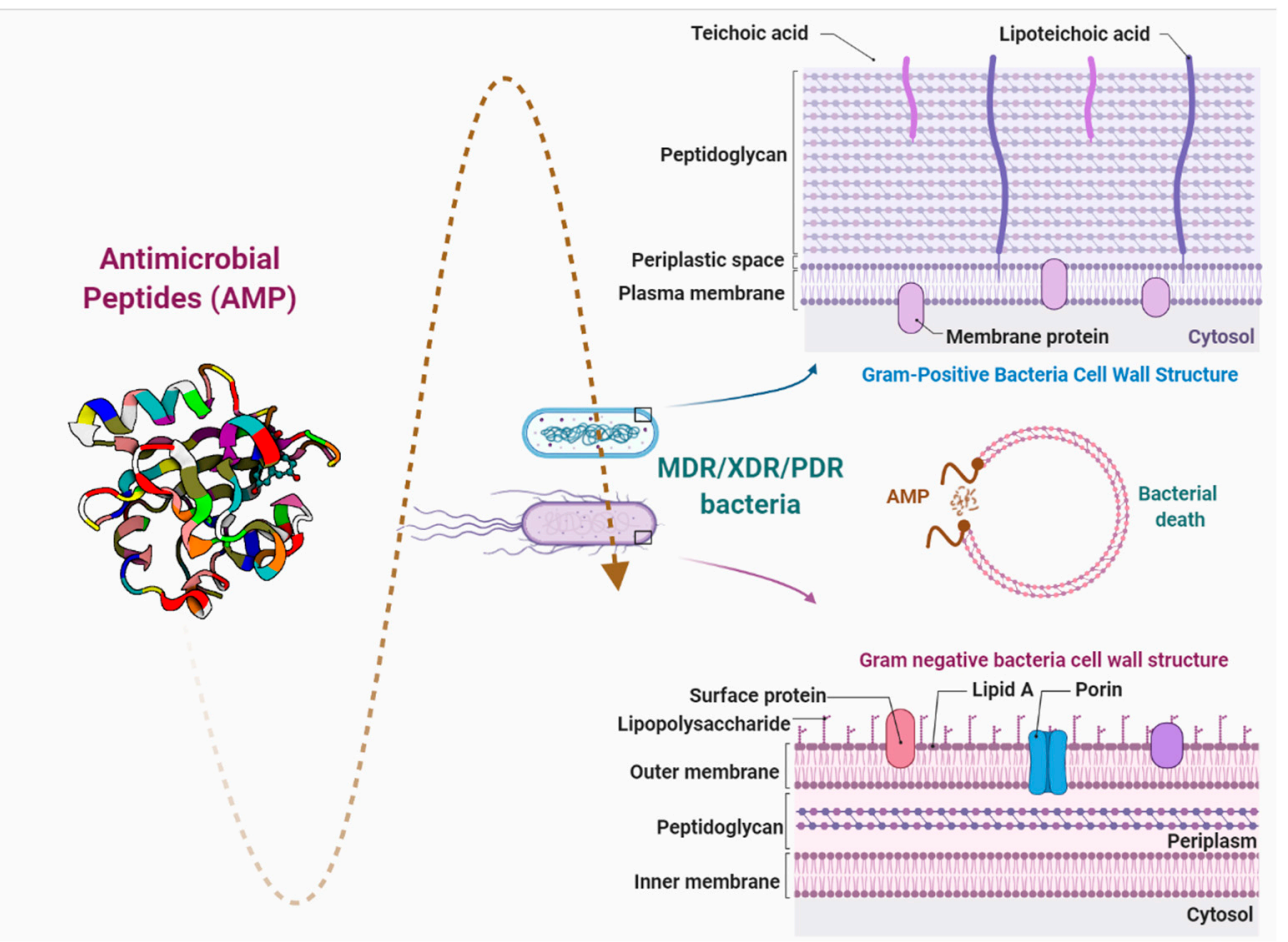

Figure 1. Brief description of the interaction between antimicrobial peptides and the bacterial cell wall. PDR: pandrug resistance, XDR: extensive drug resistance, and MDR: multidrug resistance.

\section{Why Are AMPs Highlighted in the Development of New Antibiotics?}

Innate immunity is the oldest defense system against invading microorganisms. It is the first-line mechanism to virtually protect all multicellular organisms from pathogens. Particularly, a set of biomolecules from the mammalian innate immune system is notably similar to components in other kingdoms, such as plants and insects. In this way, evidence indicates that these molecules-AMPs—could have emerged in common ancestors a long time ago, in the evolutionary processes. Defensins, a classical example of very active AMPs against fungi and bacteria, are found in plants and mammals and have essentially the same tridimensional structure in both organisms [7]. AMPs present a broad structural and functional diversity. Over the last decade, researchers have shed light on AMPs, notably receiving attention for the development of new and natural antibiotic candidates (Figure 2). AMPs are interesting for treating infections, mainly those caused by the so-called and dangerous multidrug-resistant (MDR) bacteria. Nowadays, infections caused by this group of bacteria have reached a pan-drug resistance level, which means resistance to all available conventional antibiotics. Curiously, this scenario was predicted by the penicillin discoverer, Alexander Fleming, who received a Nobel Prize in 1945 and anticipated that the global misuse of antibiotics in several areas could generate a frightening panorama [8]. 


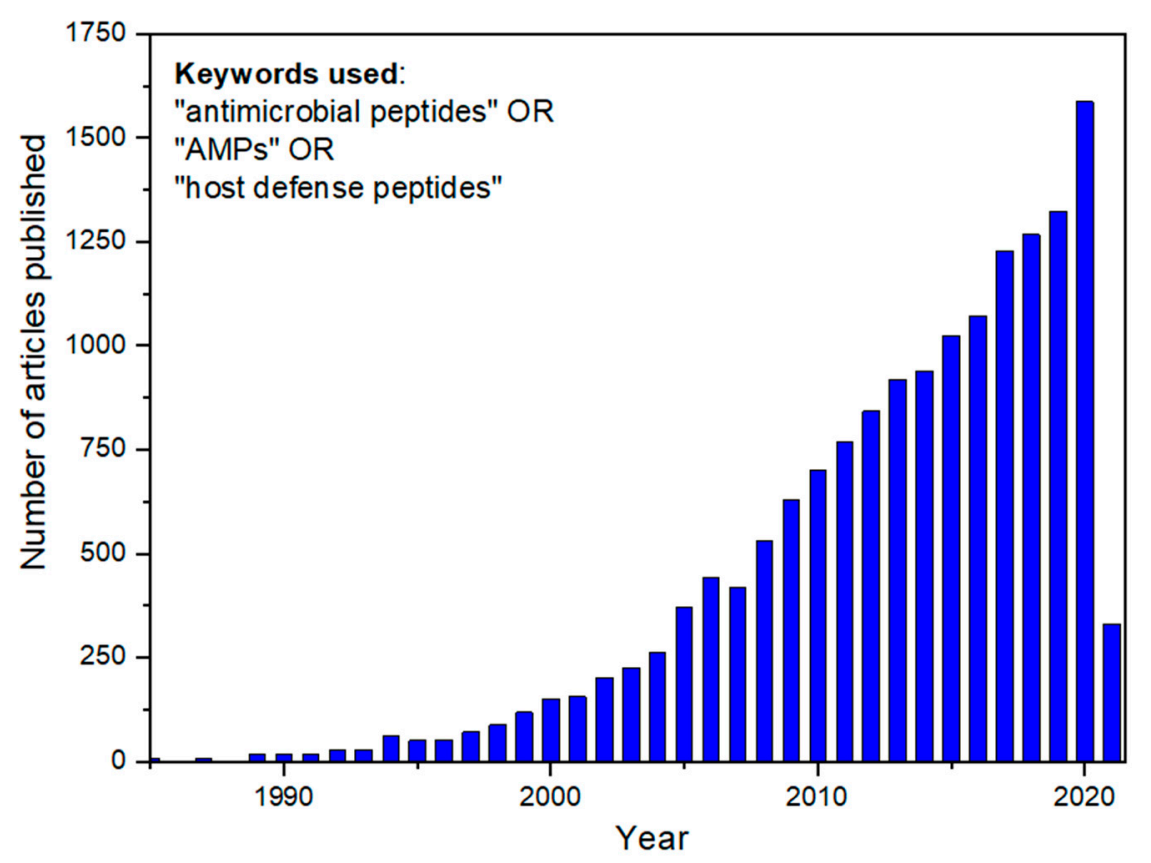

Figure 2. Number of scientific articles published in academic journals since 1985. The inset shows the keywords employed to perform the search. For the 2021 year, showing the number of articles published until the date of data search (3 March 2021), the number of papers (330) is higher than that corresponding to the whole of 2004.

AMPs share typical features, such as 8 to 50 amino acids, in the primary sequence. A cationic net charge along the structure is often observed, which can induce and facilitate an initial interaction with membrane headgroup components. There is also a predominance of hydrophobic residues, up to $50 \%$ of the entire sequence, allowing van der Waals interactions with the membrane lipid tails $[9,10]$. AMPs can adopt a broad variety of secondary structures: the helical magainin; the protegrin, which forms a $\beta$-hairpin due to the presence of a disulfide bond; the disordered indolicidin; and gramicidin, which can be cyclic [11].

AMPs display several mechanisms of action to combat pathogens. These mechanisms depend on physicochemical features such as primary and secondary structures, the number of residues, net charge, and amphipathicity [12]. Overall, they can be classified according to these properties into membrane lytic and nonlytic AMPs. There are four well-established models of membrane lytic peptides in the literature: (i) the carpet model, whereby AMPs bind to an anionic target membrane like a "carpet," covering the surface. Peptides strongly interact with the lipid head groups throughout the membrane, in a detergent-like disruption process; (ii) the toroidal pore or wormhole model, whereby the AMPs first induce the inner and outer membrane leaflet curvature and, as a consequence, align the pore lumen parallel to the phospholipid orientation, along with the headgroups. A variation of this model is the disordered toroidal pore, performed by magainin analogs and melittin, the pore formation being more stochastic and involving fewer peptide monomers; (iii) the barrel-stave pore or helical bundle model, in which the peptide monomers insert into the membrane, forming a barrel shape and open stables and transmembrane pores, which destabilize the membrane potential and promote ion and biomolecule leakage; (iv) the aggregate channel model comprises a competitive replacement of LPS-associated divalent cations, causing an unstructured aggregation of peptides and lipids, which disrupt the outer and inner membranes. In addition, other lytic membrane models, such as the lipid segregation model, oxidized lipid targeting, changes in membrane potential, and electroporation have been unveiled and described. Regarding the nonmembrane lytic peptide mechanism of action, AMPs mostly target intracellular structures, binding to DNA gyrase and topoisomerase IV, directly affecting transcription/replication. In addition, AMPs can 
inhibit protein and cell wall biosynthesis, inactivate enzyme activities in ribosomes, and cause cellular apoptosis $[9,11,13]$.

AMPs can be obtained by chemical synthesis or recombinant production systems. Specifically, the latter typically demands a long and expensive research and development phase, exhibiting some limitations in terms of modifications in the peptide sequence. However, the artificial synthesis of AMPs provides interesting advantages from natural or recombinant obtainment processes. In the solid-phase peptide synthesis (SPPS), amino acids are sequentially added to a solid support, which is considered the most commonly used and mature technology available for AMPs, even for the production of peptides with up to 50 amino acid residues [14]. A detailed approach to the SPPS method is described elsewhere [15]. Interestingly, SPPS offers a precise modification of AMP primary sequences, to modulate their biological activity against different types of pathogens and evaluate structure-activity relationships. Moreover, the design of AMPs via chemical synthesis can incorporate unusual and nonnatural amino acids to study the backbone conformation, dynamics in the membrane, and solution and orientation of peptides [16,17], via spectroscopy techniques [18,19].

Although AMPs are considered a valuable candidate for a new line of antibiotic compounds to tackle bacterial resistance, there are still many challenges to be overcome: (i) poor biostability by proteolytic degradation; (ii) cytotoxicity/high hemolytic activities at concentrations closer to therapeutic dosages; (iii) the lack of efficient delivery systems to the target site for effective release concentrations; and (iv) high manufacturing costs. In this way, the main objective of researchers and biotechnological and pharmaceutical companies is the production of AMPs that are highly selective against pathogenic bacteria, exhibiting higher therapeutic indexes. There are currently several successful AMPs in phase 3 of clinical trials, such as Omiganan, IMX942 (topical application); Surotomycin and Talactoferrin (oral); and Murepavadin and p2TA (intravenous) [11,20]. These AMPs have different targets and mechanisms of action and have aroused high expectations about the development and registration of safer, efficient, and natural antibiotics to combat MDR bacteria and avoid a chaotic future scenario.

\section{Critical Bacterial Resistance}

The great global concern regarding bacterial resistance to drugs has led the WHO to publish priority lists of bacteria for research and new drugs that may help reduce or control this problem. This list has been separated into critical-priority (CPB), high-priority (HPB), and medium-priority bacteria [21] according to the resistance of the antimicrobials currently used.

In its latest updates, between 2015 and 2017, the FDA approved the use of avibactam, bezlotoxumab, ceftazidime, delafloxacin, malacidin, obiltoxaximab, ozenoxacin, teixobactin, vabomere, and vaborbactam [22], and in 2018-2019, cefiderocol, cilastatin, relebactam, eravacycline, imipenem, lefamulin, omadacycline, rifamycin, plazomicin, pretomanid, sarecycline [23]. The mechanisms of action and antimicrobial activity of the new drugs are described in Table 1, published by the FDA between 2017 and 2021. 
Table 1. New FDA-approved drugs; detailed review 2017-2021 [24].

\begin{tabular}{|c|c|c|c|c|c|}
\hline Drug & Approval Date & $\begin{array}{c}\text { FDA-Approved } \\
\text { Application }\end{array}$ & & Mechanism of Action & Antibacterial Activity \\
\hline cefiderocol & $\begin{array}{l}14 \text { November } \\
2019\end{array}$ & $\begin{array}{l}\text { To treat patients } \\
\text { with complicated } \\
\text { urinary tract } \\
\text { infections who have } \\
\text { limited or no } \\
\text { alternative } \\
\text { treatment options }\end{array}$ & - & $\begin{array}{l}\text { Cephalosporin with activity against } \\
\text { Gram-negative aerobic bacteria. } \\
\text { Functions as a siderophore and } \\
\text { binds to extracellular free ferric iron. } \\
\text { Passive diffusion via porin channels. } \\
\text { Actively transported across the } \\
\text { outer cell membrane of bacteria into } \\
\text { the periplasmic space using a } \\
\text { siderophore iron uptake mechanism. } \\
\text { Cefiderocol exerts bactericidal } \\
\text { action by inhibiting cell wall } \\
\text { biosynthesis through binding to } \\
\text { penicillin-binding proteins (PBPs). }\end{array}$ & $\begin{array}{l}\text { Gram-negative: Escherichia } \\
\text { coli, Enterobacter cloacae } \\
\text { complex, Klebsiella } \\
\text { pneumoniae, Proteus } \\
\text { mirabilis, Pseudomonas } \\
\text { aeruginosa, Acinetobacter } \\
\text { baumannii, Citrobacter } \\
\text { freundii complex, Citrobacter } \\
\text { koseri, Klebsiella aerogenes, } \\
\text { Klebsiella oxytoca, } \\
\text { Morganella morganii, Proteus } \\
\text { vulgaris, Providencia rettgeri, } \\
\text { Serratia marcescens, } \\
\text { Stenotrophomonas } \\
\text { maltophilia. }\end{array}$ \\
\hline $\begin{array}{l}\text { imipenem, } \\
\text { cilastatin, } \\
\text { and } \\
\text { relebactam }\end{array}$ & 16 July 2019 & $\begin{array}{c}\text { To treat } \\
\text { complicated } \\
\text { urinary tract and } \\
\text { complicated } \\
\text { intra-abdominal } \\
\text { infections }\end{array}$ & - & $\begin{array}{l}\text { Imipenem is a penem antibacterial } \\
\text { drug, cilastatin sodium is a renal } \\
\text { dehydropeptidase inhibitor, and } \\
\text { relebactam is a beta lactamase } \\
\text { inhibitor. } \\
\text { Cilastatin limits the renal } \\
\text { metabolism of imipenem and does } \\
\text { not have antibacterial activity. The } \\
\text { bactericidal activity of imipenem } \\
\text { results from the binding to PBP } 2 \\
\text { and PBP 1B in Enterobacteriaceae } \\
\text { and Pseudomonas aeruginosa and the } \\
\text { subsequent inhibition of PBPs. } \\
\text { Inhibition of PBPs leads to the } \\
\text { disruption of bacterial cell wall } \\
\text { synthesis. Imipenem is stable in the } \\
\text { presence of some beta lactamases. } \\
\text { Relebactam has no intrinsic } \\
\text { antibacterial activity, and it protects } \\
\text { imipenem from degradation by } \\
\text { certain serine beta lactamases such } \\
\text { as Sulhydryl Variable (SHV), } \\
\text { Temoneira (TEM), and } \\
\text { Cefotaximase-Munich. }\end{array}$ & $\begin{array}{l}\text { Complicated Urinary Tract } \\
\text { Infections and Complicated } \\
\text { Intra-abdominal Infections. } \\
\text { Some important bacters: } \\
\text { Citrobacter freundii, } \\
\text { Klebsiella aerogenes, } \\
\text { Enterobacter cloacae, } \\
\text { Escherichia coli, Klebsiella } \\
\text { oxytoca, Klebsiella } \\
\text { pneumoniae, Pseudomonas } \\
\text { aeruginosa, Bacteroides } \\
\text { caccae, Bacteroides fragilis, } \\
\text { Bacteroides ovatus, } \\
\text { Bacteroides stercoris, } \\
\text { Bacteroides thetaiotaomicron, } \\
\text { Bacteroides uniformis, } \\
\text { Bacteroides vulgatus, } \\
\text { Fusobacterium nucleatum, } \\
\text { Parabacteroides distasonis. } \\
\text { Enterococcus faecalis, } \\
\text { Methicillin-susceptible } \\
\text { Staphylococcus aureus, } \\
\text { Streptococcus anginosus, } \\
\text { Streptococcus constellatus. } \\
\text { Citrobacter koseri, } \\
\text { Enterobacter asburiae, etc. }\end{array}$ \\
\hline lefamulin & 19 August 2019 & $\begin{array}{l}\text { To treat adults with } \\
\text { community- } \\
\text { acquired bacterial } \\
\text { pneumonia }\end{array}$ & - & $\begin{array}{l}\text { Systemic pleuromutilin } \\
\text { antibacterial. } \\
\text { Inhibits bacterial protein synthesis } \\
\text { through interactions (hydrogen } \\
\text { bonds, hydrophobic interactions, } \\
\text { and van der Waals forces) with the } \\
\text { A- and P-sites of the peptidyl } \\
\text { transferase center (PTC) in domain } \\
\text { V of the } 23 \text { s rRNA of the } 50 S \text { subunit. } \\
\text { The binding pocket of the bacterial } \\
\text { ribosome closes around the mutilin } \\
\text { core for an induced fit that prevents } \\
\text { the correct positioning of tRNA. }\end{array}$ & $\begin{array}{l}\text { S. pneumoniae, H. Influenzae, } \\
\text { and } M \text {. pneumoniae } \\
\text { (including } \\
\text { macrolide-resistant strains), } \\
\text { and bacteriostatic against } S \text {. } \\
\text { aureus, and } S \text {. pyogenes at } \\
\text { clinically relevant } \\
\text { concentrations }\end{array}$ \\
\hline pretomanid & 14 August 2019 & $\begin{array}{l}\text { For } \\
\text { treatment-resistant } \\
\text { forms of } \\
\text { tuberculosis that } \\
\text { affect the lungs }\end{array}$ & - & $\begin{array}{l}\text { Nitroimidazooxazine } \\
\text { antimycobacterial drug. } \\
\text { inhibiting mycolic acid biosynthesis, } \\
\text { thereby blocking cell wall } \\
\text { production. }\end{array}$ & $\begin{array}{l}\text { Mutations in five } M \text {. } \\
\text { tuberculosis genes (ddn, } \\
\text { fgd1, fbiA, fbiB, and fbiC) } \\
\text { have been associated with } \\
\text { pretomanid resistance. }\end{array}$ \\
\hline
\end{tabular}


Table 1. Cont.

\begin{tabular}{|c|c|c|c|c|}
\hline Drug & Approval Date & $\begin{array}{l}\text { FDA-Approved } \\
\text { Application }\end{array}$ & Mechanism of Action & Antibacterial Activity \\
\hline omadacycline & 2 October 2018 & $\begin{array}{l}\text { To treat community- } \\
\text { acquired bacterial } \\
\text { pneumonia and } \\
\text { acute bacterial skin } \\
\text { and skin structure } \\
\text { infections }\end{array}$ & $\begin{array}{l}\text { - } \begin{array}{l}\text { Aminomethylcycline antibacterial } \\
\text { (tetracycline class of antibacterial }\end{array} \\
\text { drugs). } \\
\text { - } \quad \text { The drug binds to the 30S ribosomal } \\
\text { subunit and blocks protein } \\
\text { synthesis. } \\
\text { Active in vitro against } \\
\text { Gram-positive bacteria expressing } \\
\text { tetracycline resistance active efflux } \\
\text { pumps (tetK and tet L) and } \\
\text { ribosomal protection proteins (tet } \\
\text { M). In general, omadacycline is } \\
\text { considered bacteriostatic; however, } \\
\text { omadacycline has demonstrated } \\
\text { bactericidal activity against some } \\
\text { isolates of S. pneumoniae and } H . \\
\text { influenzae. }\end{array}$ & $\begin{array}{l}\text { Gram-positive bacteria that } \\
\text { carried ribosomal } \\
\text { protection genes (tet } \mathrm{M} \text { ) } \\
\text { and efflux genes (tet } \mathrm{K} \text { and } \\
\text { tet L), and in } \\
\text { Enterobactericeae that } \\
\text { carried the tetB efflux gene. } \\
\text { Some S. aureus, S. } \\
\text { pneumoniae, and H. } \\
\text { influenzae strains carrying } \\
\text { macrolide resistance genes } \\
\text { (erm A, B, and/or C), or } \\
\text { ciprofloxacin resistance } \\
\text { genes (gyrA and parC) and } \\
\text { beta-lactamase-positive } H \text {. } \\
\text { influenzae. }\end{array}$ \\
\hline eravacycline & 27 August 2018 & $\begin{array}{l}\text { To treat } \\
\text { complicated } \\
\text { intra-abdominal } \\
\text { infections in } \\
\text { patients } 18 \text { years of } \\
\text { age and older }\end{array}$ & $\begin{array}{l}\text { - Fluorocycline antibacterial } \\
\text { (tetracycline class of antibacterial } \\
\text { drugs). } \\
\text { This drug disrupts bacterial protein } \\
\text { synthesis by binding to the } 30 S \\
\text { ribosomal subunit, thus preventing } \\
\text { the incorporation of amino acid } \\
\text { residues into elongating peptide } \\
\text { chains. }\end{array}$ & $\begin{array}{l}\text { In general, is bacteriostatic } \\
\text { against Gram-positive } \\
\text { bacteria (e.g., } \\
\text { Staphylococcus aureus and } \\
\text { Enterococcus faecalis); } \\
\text { however, in vitro } \\
\text { bactericidal activity has } \\
\text { been demonstrated against } \\
\text { certain strains of Escherichia } \\
\text { coli and K. pneumoniae. }\end{array}$ \\
\hline plazomicin & 25 June 2018 & $\begin{array}{l}\text { To treat adults with } \\
\text { complicated } \\
\text { urinary tract } \\
\text { infections }\end{array}$ & $\begin{array}{l}\text { Aminoglycoside that acts by } \\
\text { binding to the bacterial } 30 S \\
\text { ribosomal subunit, thereby } \\
\text { inhibiting protein synthesis. }\end{array}$ & $\begin{array}{l}\text { Enterobacteriaceae in the } \\
\text { presence of } \\
\text { certain beta-lactamases, } \\
\text { including } \\
\text { extended-spectrum } \\
\text { beta-lactamases (TEM, } \\
\text { SHV, CTX-M, AmpC), } \\
\text { serine carbapenemases } \\
\text { (KPC-2, KPC-3), and } \\
\text { oxacillinase (OXA-48). } \\
\text { Bacteria producing } \\
\text { metallo-beta-lactamases } \\
\text { often co-express 16S rRNA } \\
\text { methyltransferase, } \\
\text { conferring resistance to } \\
\text { plazomicin. }\end{array}$ \\
\hline secnidazole & $\begin{array}{l}15 \text { September } \\
2017\end{array}$ & $\begin{array}{c}\text { To treat bacterial } \\
\text { vaginosis }\end{array}$ & $\begin{array}{l}\text { 5-nitroimidazole antimicrobial. } \\
\text { - } \\
\text { cell as an inactive prodrug where the } \\
\text { nitro group is reduced by bacterial } \\
\text { enzymes to radical anions. It is } \\
\text { believed that these radical anions } \\
\text { interfere with the bacterial DNA } \\
\text { synthesis of susceptible isolates. }\end{array}$ & $\begin{array}{l}\text { Bacteroides spp., Gardnerella } \\
\text { vaginalis, Prevotella spp., } \\
\text { Mobiluncus spp., } \\
\text { Megasphaera-like type I/II }\end{array}$ \\
\hline
\end{tabular}


Table 1. Cont.

\begin{tabular}{|c|c|c|c|c|c|}
\hline Drug & Approval Date & $\begin{array}{c}\text { FDA-Approved } \\
\text { Application }\end{array}$ & & Mechanism of Action & Antibacterial Activity \\
\hline $\begin{array}{l}\text { meropenem } \\
\text { and vabor- } \\
\text { bactam }\end{array}$ & 29 August 2017 & $\begin{array}{l}\text { To treat adults with } \\
\text { complicated } \\
\text { urinary tract } \\
\text { infections }\end{array}$ & - & $\begin{array}{l}\text { The meropenem is a penem } \\
\text { antibacterial drug. } \\
\text { The bactericidal action of } \\
\text { meropenem results from the } \\
\text { inhibition of cell wall synthesis. } \\
\text { Meropenem penetrates the cell wall } \\
\text { of most Gram-positive and } \\
\text { Gram-negative bacteria to bind PBP } \\
\text { targets. Meropenem is stable to } \\
\text { hydrolysis by most beta-lactamases, } \\
\text { including penicillinases and } \\
\text { cephalosporinases produced by } \\
\text { Gram-negative and Gram-positive } \\
\text { bacteria, with the exception of } \\
\text { carbapenem hydrolyzing } \\
\text { beta-lactamases. The vaborbactam is } \\
\text { a nonsuicidal beta-lactamase } \\
\text { inhibitor that protects meropenem } \\
\text { from degradation by certain serine } \\
\text { beta-lactamases such as Klebsiella } \\
\text { pneumoniae carbapenemase (KPC). } \\
\text { Vaborbactam does not have any } \\
\text { antibacterial activity. Vaborbactam } \\
\text { does not decrease the activity of } \\
\text { meropenem against } \\
\text { meropenem-susceptible organisms. }\end{array}$ & $\begin{array}{l}\text { Gram-negative bacteria: } \\
\text { Enterobacter cloacae species } \\
\text { complex, Escherichia coli, } \\
\text { Klebsiella pneumoniae, } \\
\text { Citrobacter freundii, } \\
\text { Citrobacter koseri, } \\
\text { Enterobacter aerogenes, } \\
\text { Klebsiella oxytoca, } \\
\text { Morganella morganii, Proteus } \\
\text { mirabilis, Providencia spp., } \\
\text { Pseudomonas aeruginosa, } \\
\text { Serratia marcescens. }\end{array}$ \\
\hline delafloxacin & 19 June 2017 & $\begin{array}{l}\text { To treat patients } \\
\text { with acute bacterial } \\
\text { skin infections }\end{array}$ & - & $\begin{array}{l}\text { Fluoroquinolone class of } \\
\text { antibacterial drugs and is anionic in } \\
\text { nature. } \\
\text { Inhibition of both bacterial } \\
\text { topoisomerase IV and DNA gyrase } \\
\text { (topoisomerase II) enzymes, which } \\
\text { are required for bacterial DNA } \\
\text { replication, transcription, repair, and } \\
\text { recombination. }\end{array}$ & $\begin{array}{l}\text { Gram-positive bacteria } \\
\text { Staphylococcus aureus } \\
\text { (including } \\
\text { methicillin-resistant and } \\
\text { methicillin-sensitive } \\
\text { strains), Staphylococcus } \\
\text { haemolyticus, Staphylococcus } \\
\text { lugdunensis, Streptococcus } \\
\text { pyogenes, Streptococcus } \\
\text { agalactiae, Streptococcus } \\
\text { anginosus Group (including } \\
\text { S. anginosus, S. intermedius, } \\
\text { and S. constellatus), } \\
\text { Enterococcus faecalis, } \\
\text { Streptococcus dysgalactiae. } \\
\text { Gram-negative bacteria } \\
\text { E. coli, K. pneumoniae, } \\
\text { Enterobacter cloacae, P. } \\
\text { aeruginosa, Enterobacter } \\
\text { aerogenes, Haemophilus } \\
\text { parainfluenzae, Klebsiella } \\
\text { oxytoca, Proteus mirabilis. }\end{array}$ \\
\hline
\end{tabular}

For a better understanding of the bacterial resistance of this priority list of bacteria, the classification of conventional drugs used worldwide is shown in Table 2 (where the new drugs mentioned above are not listed). 
Table 2. Classification of antimicrobial agents according to the Food and Drug Administration (FDA) [25].

\begin{tabular}{|c|c|c|c|c|}
\hline & Group & Sub-Group & Classification & Main Drugs \\
\hline \multirow{39}{*}{$\begin{array}{l}\text { Antimicrobial } \\
\text { agents }\end{array}$} & \multirow{31}{*}{ B-Lactamic } & \multirow{13}{*}{ Penicillins } & \multirow{4}{*}{$\begin{array}{l}\text { natural penicillins or } \\
\text { benzilpenicillins }\end{array}$} & crystalline penicillin \\
\hline & & & & penicillin $\mathrm{G}$ procaine \\
\hline & & & & benzathine penicillin $G$ \\
\hline & & & & penicillin $\mathrm{V}$ \\
\hline & & & \multirow{2}{*}{ aminopenicillins } & ampicillin \\
\hline & & & & amoxicillin \\
\hline & & & \multirow{7}{*}{$\begin{array}{l}\text { penicillins resistant to } \\
\text { penicillinases }\end{array}$} & oxacillin \\
\hline & & & & methicillin \\
\hline & & & & carbenicillin \\
\hline & & & & ticarcillin \\
\hline & & & & piperacillin \\
\hline & & & & $\begin{array}{c}\text { carboxypenicillins } \\
\text { (carbenicillin and ticarcillin) }\end{array}$ \\
\hline & & & & $\begin{array}{l}\text { ureido-penicillins (mezlocillin, } \\
\text { piperacillin, and azlocillin) }\end{array}$ \\
\hline & & \multirow{11}{*}{ Cephalosporins } & \multirow{4}{*}{ 1st generation } & cephalothin \\
\hline & & & & cefazolin \\
\hline & & & & cephalexin \\
\hline & & & & cefadroxil \\
\hline & & & \multirow{3}{*}{ 2nd generation } & cefoxitin \\
\hline & & & & cefuroxime \\
\hline & & & & cefaclor \\
\hline & & & \multirow{3}{*}{ 3rd generation } & cefotaxime \\
\hline & & & & ceftriaxone \\
\hline & & & & ceftazidime \\
\hline & & & 4th generation & cefepime \\
\hline & & \multirow{6}{*}{ Carbapenems } & \multirow{6}{*}{-} & Imipenem \\
\hline & & & & meropenem \\
\hline & & & & ertapenem \\
\hline & & & & doripenem \\
\hline & & & & biapenem \\
\hline & & & & tebipenem \\
\hline & & Monobactams & - & aztreonem \\
\hline & \multirow{4}{*}{ Quinolones } & & & levofloxacin \\
\hline & & - & - & gatifloxacin \\
\hline & & & & moxifloxacin \\
\hline & & & & gemifloxacin \\
\hline & & & & vancomycin \\
\hline & Glycopeptides & - & - & teicoplanin \\
\hline & & & & branchplanin \\
\hline & Oxazolidinones & - & - & linezolid \\
\hline
\end{tabular}


Table 2. Cont.

\begin{tabular}{|c|c|c|c|}
\hline Group & Sub-Group & Classification & Main Drugs \\
\hline \multirow{7}{*}{ Aminoglycosides } & \multirow{7}{*}{-} & \multirow{7}{*}{-} & streptomycin \\
\hline & & & gentamicin \\
\hline & & & tobramycin \\
\hline & & & amikacin \\
\hline & & & netilmicin \\
\hline & & & paromomycin \\
\hline & & & spectinomycin \\
\hline \multirow{6}{*}{ Macrolides } & \multirow{6}{*}{-} & \multirow{6}{*}{-} & azithromycin \\
\hline & & & clarithromycin \\
\hline & & & erythromycin \\
\hline & & & spiramycin \\
\hline & & & myocamycin \\
\hline & & & roxithromycin \\
\hline Lincosamines & - & - & lincomycin \\
\hline Nitroimidazole & - & - & metronidazole \\
\hline Chloramphenicol & - & - & chloramphenicol \\
\hline \multirow{2}{*}{ Streptogramins } & \multirow{2}{*}{-} & \multirow{2}{*}{-} & quinupristin \\
\hline & & & dalfopristin \\
\hline \multirow{5}{*}{ Sulfonamides } & \multirow{5}{*}{-} & \multirow{5}{*}{-} & sulfanilamide \\
\hline & & & sulfisoxazole \\
\hline & & & sulfacetamide \\
\hline & & & para-aminobenzoic acid \\
\hline & & & $\begin{array}{l}\text { sulfadiazine and } \\
\text { sulfamethoxazole }\end{array}$ \\
\hline Tetracyclines & - & - & tetracyclines \\
\hline \multirow{4}{*}{ New Antimicrobials } & Glycylcyclines & - & tigecycline \\
\hline & \multirow{2}{*}{ Polymyxins } & \multirow{2}{*}{-} & colistin (polymyxin E) \\
\hline & & & polymyxin B \\
\hline & Daptomycin & - & daptomycin \\
\hline
\end{tabular}

The bacterial resistance to beta-lactam and quinolone drugs is highlighted on the CPB list, leading to strong interest in developing new drugs and pharmaceutical combinations [26]. Beta-Lactam drugs are a broad class of antibiotics consisting of a $\beta$-lactam ring and a broad spectrum, which act as inhibitors of cell wall formation, preventing peptidoglycan biosynthesis [27]. All antibiotics of this class (except for tabtoxinine- $\beta$-lactam, which inhibits glutamine synthetase) bind to penicillin-binding proteins (PBPs), a type of transpeptidase responsible for the synthesis of the bacterial cell wall [28]. Resistance to carbapenems is the main concern of the WHO [26]. Carbapenem drugs ( $\beta$-lactam group) are used in the treatment of highly uncontrollable multidrug-resistant (MDR) bacterial diseases. Their action also allows the blocking of cell wall formation by interrupting peptidoglycan transpeptidation in the cell wall [29]. Over the years, several drugs of this subgroup have been discovered and approved, such as imipenem (1985), meropenem (1993), panipenem/betamipron (1993), ertapenem (2001), doripenem (2007), biapenem 
(2001), and tebipenem (2015). Despite being excellent bacterial inhibitors, many bacterial strains have developed resistance [30].

The first report of bacterial resistance to $\beta$-lactams was on penicillins (1940) through hydrolysis reaction, efflux pumps, and alterations of the target, producing, in many cases, certain enzymes known as $\beta$-lactamases, which inactivate the action of these drugs (hydrolyzing $\beta$-lactam bonds) [27]. Other studies prioritize AMP-drug activity (synergic effect) to enhance the action of carbapenems, as recently reported, using meropenem-vaborbactam to kill high-risk bacteria with resistance to carbapenems. Vaborbactam is a boron-based inhibitor that inactivates the action of Klebsiella pneumoniae carbapenemase (KPC), which does not have antibacterial activity when used unimolecularly [31], Imipenem-cilastatin [32], and Imipenem-cilastatin-relebactam [32,33]. The combined activity or synergistic effect has had positive results in recent years, and its mechanisms still need to be studied in depth.

Resistance to fluoroquinolones was also highlighted out on this list because different drugs, such as ciprofloxacin, were used to treat infectious diseases such as Moraxella catarrhalis, Haemophilus influenzae, Streptococcus pneumoniae, Neisseria gonorrhoeae, and Enterobacteria. Due to their uncontrolled use and/or the discontinuation of treatment, new mutations were reported worldwide [34-36]. The action of fluoroquinolones occurs by the accumulation of -OH radicals, chromosomal fragmentation, and an increase in reactive oxygen species. However, similar to carbapenems, quinolone-resistant bacteria also present resistance mechanisms such as efflux pumps and enzymes, diverting the drug target, reducing drug accumulation, and/or generating defense plasmids [37]. AMP-drug activity was also reported to have a synergistic effect between Melimine, Protamine, and Mel4, together with ciprofloxacin and cefepime, which resulted in the elimination of all MDR bacteria with lower minimal inhibition concentration (MIC) values, thus enhancing the use of these two drugs, which, by themselves, lose their action against MDR bacteria [38].

Other drug resistances shown in the WHO list involve glycopeptides, which are frequently used against enterococci, streptococci, and MDR staphylococci. Among them, vancomycin and teicoplanin, derived from Actinobacteria, are included on the HPB list [39]. These drugs act by binding to the peptidoglycan ends of the cell membrane (binding between the D-Ala-D-Ala dipeptide and Lipid II precursor); this reduces the activity of transglycosylases and transpeptidases, thus blocking bacterial replication caused by a metabolic imbalance, until cell death [40]. Telavancin, Dalbavancin, and Oritavancin were the last drugs approved and FDA-incorporated as treatments, as reported until 2018 [39]. However, bacterial resistance in this group of drugs occurs mainly to vancomycins, when these bacteria replace the production of D-Ala-D-Ala by D-Ala- $X, X$ being a D-Lac (vanA, vanB, and vanC) or D-Ser, which removes one of the five bonds formed by vancomycin, and, therefore, they lose their affinity and effectiveness [39]. This effect improved when a conjugate of vancomycin with cationic AMP, known as FU002, was used. This conjugate made it possible to drastically decrease the MIC values in several Staphylococcus aureus methicillin-resistant (MRSA) strains, increasing its effect 1000 times and achieving a profile of controlled biodistribution [41]. For an in-depth review of glycopeptide-resistant bacteria, see Blaskovich et al. [39].

Likewise, AMPs have shown strong performance against bacteria resistant to macrolides such as clarithromycin. This resistance is generally caused by mutations alleged to Helicobacter pylori, which is installed in the gastric mucosa and is the main cause of stomach cancer in the world [42]. This macrolide binds to the 50S subunit, inhibiting protein synthesis and, consequently, its replication. Resistance to macrolides is produced by the genetic alteration of rRNA $23 \mathrm{~S}$ and the production of efflux pumps, which hinders the action mainly of clarithromycin [43]. AMP T4 was described as a promising peptide because it acts independently of the type of resistance, evaluated against $H$. pylori MDR and showing better results than the drugs usually used [44]. 
In summary, the application and design of new AMP or AMP homologs are necessary to meet the demand for new drugs against resistant bacteria. Various studies of AMPs against these MDR, extensively drug-resistant (XDR), and pan-drug resistant (PDR) bacteria were reviewed and classified according to their location on the WHO-list (CPB and HPB).

\section{AMP Applications in Critical-Priority Bacteria}

The CPB list groups Acinetobacter baumannii and Pseudomonas aeruginosa, carbapenemresistants, Enterobacteriaceae (Klebsiella pneumoniae, Escherichia coli, Enterobacter spp., Serratia spp., Proteus spp., Providencia spp., and Morganella spp.), carbapenem-resistant (CRE), third-generation cephalosporin-resistant, and Mycobacterium tuberculosis [21].

All the bacteria on this list show severe antimicrobial resistance, and most reported cases are found in patients admitted to intensive care units (ICUs). Acinetobacteria sp. are a special group of microorganisms present in the ICU that easily acquire resistance to antibiotics during the treatment of patients hospitalized for other diseases. In particular, A. baumannii causes pneumonia and dermal and urethral infections [45]. This large-negative bacterium, in the form of a coccobacillus, belongs to the group of opportunistic bacteria and the reservoir of resistance genes that is more difficult to control [46]. Due to these parameters, carbapenems were the most efficient treatment against these bacteria until the last decade, when new bacterial strains with resistance to carbapenems were reported, which was even more worrying [29].

A. baumannii can generate resistance by enzymatic or nonenzymatic routes. It was observed in recent years that the alteration of PBPs would be involved in a mechanism of resistance to $\beta$-lactam drugs and, consequently, to carbapenems $[47,48]$. In addition, the ratio of the decrease in the size of the outer membrane proteins (OMP), known in A. baumannii as CarO proteins, would be the main way to identify their nonenzymatic resistance. Another means would be the presence of active expulsion or efflux pumps, which are the main source of bacterial resistance in all MDR bacteria [29]. Commonly used drugs for this type of MDR bacteria are colistin sulfate, tobramycin, levofloxacin, kanamycin, and carbenicillin disodium [49]. Different successful studies were carried out to eliminate this bacterium with AMPs, as listed in Table 2.

$P$. aeruginosa causes lung inflammation due to the release of IL- 6 and TNF- $\alpha$ induced by their LPS, which are associated with cystic fibrosis and chronic obstructive pulmonary disease [49]. They are difficult bacteria to treat, and like A. baumannii, many of those with MDR or XDR are biofilm-forming, which prevents the action of most drugs [50]. In the same way, combined studies of AMP-drugs have been carried out to improve their bactericidal activity, and even AMPs have been considered new biomolecules with antibiofilm action, which allows the promotion of the development of new drugs for this list of potentially infectious bacteria [51,52].

Enterobacteriaceae have become a family of problematic bacteria due to the ease of resistance and the production of extended-spectrum $\beta$-lactamases and carbapenemases (KPC and others), which induce carbapenem-resistant Enterobacteriaceae (CRE) infections [53,54]. Klebsiella pneumoniae MDR is a highly complex bacterium to treat and, due to its persistence, the mortality rate in humans continues to increase. The use of polymyxin (polypeptides approved by the FDA) has been intensified to combat many MDRs, as this peptide helps to improve the action of obsolete drugs during treatment [54]. A study revealed that there are certain amino acid conformations of peptides that could efficiently fight this type of MDR/XDR/PDR bacteria by modifying the conformation of this capsule, although there is an unknown information barrier to explain this event that must be explored [55]. An in-depth study of CRE was reported by Suay-García et al. [54].

Mycobacterium tuberculosis is a bacterium that causes a high mortality rate worldwide. It has distinct defense mechanisms, in comparison with other bacteria, due to its capsule composition of peptidoglycans. It is also capable of remaining in the latency phase for many years with no symptoms of infection [56]. Thus, many studies against this bacterium have been carried out at the genetic-molecular and biochemical levels to reach new therapeutic 
objectives and control it, as conventional antibiotics are not effective enough, require a long time, and cause unpleasant adverse effects [57]. A study reported that the regulation between the relationship of cortisol and dehydroepiandrosterone in the human body could be related to the human immune response to tuberculosis, and this relationship could increase or decrease the production of innate AMPs, such as cathelicidin LL-37, and human $\beta$-defensin 2 and 3, to combat this bacterium [58]. The use of AMPs against tuberculosis or the regulation of their innate production is an attractive option that has created great expectations.

In a recent study, Abraham et al. [56] synthesized a 21-residue peptide called B1CTcu5, which was originally isolated from the cutaneous secretion of Clinotarsus curtipes, a frog of Indian origin. The brevinin-1 family of AMP has shown promising results in the search for a new agent against tuberculosis. It was able to selectively kill intracellular bacteria without causing damage to macrophages and had an overall hydrophobicity of $65 \%$. The hydrophobic nature of the peptide may act as a driving force to move from an aqueous environment to a hydrophobic one and increase its affinity for the acyl lipid chains of the membrane. The hydrophobic interaction between amphipathic AMP and the cell membrane forms a specific peptide-lipid complex, which can produce changes in the bacterial membrane, such as thinning, pore formation, altered curvature, and localized alterations. The AMP can translocate across the membrane and diffuse into the cytoplasm, possibly interacting with intracellular targets. According to Orme et al. [59], potential compounds should have $<10 \mu \mathrm{g} / \mathrm{mL}$ MIC values. Most therapeutic drugs are effective below $1 \mu \mathrm{g} / \mathrm{mL}$. Table 3 shows AMPs designed to have great antimicrobial activity against $\mathrm{CPB}$. The analysis was based on a systematic review in the ScienceDirect database and Google scholar search engine in 2019-2021.

Table 3. Several reviews (2019 to 2021) of antimicrobial peptides applied against WHO-list (CPB).

\begin{tabular}{|c|c|c|c|c|c|c|}
\hline AMPs & Peptide Sequence & $\underset{(\mu \mathrm{gI} / \mathrm{mL})}{\mathrm{MIC}}$ & System & Natural Source & $\begin{array}{c}\text { PDR/MDR/XDR } \\
\text { Bacteria }\end{array}$ & Ref. \\
\hline \multirow{2}{*}{ ZY4 peptide } & \multirow{2}{*}{$\begin{array}{l}\text { VCKRWKKWKRKWKKWCV } \\
\text { In the sequence, disulfide } \\
\text { bond }(C-C) \text { is formed by the } \\
\text { Cystein. }\end{array}$} & $2.0-4.5$ & \multirow{2}{*}{$\begin{array}{l}\text { In vitro/ } \\
\text { In vivo }\end{array}$} & \multirow{2}{*}{$\begin{array}{l}\text { Snake venom of } \\
\text { Bungarus } \\
\text { fasciatus }\end{array}$} & $\begin{array}{c}\text { P. aeruginosa (CICC21625, } \\
\text { CMCC10104, C1, C2, C3, } \\
\text { and C5) }\end{array}$ & \multirow{2}{*}[49]{} \\
\hline & & $4.6-9.4$ & & & $\begin{array}{l}\text { A. baumannii (22933, } \\
\text { CN40, 18C116, 18C132, } \\
\text { 18C135, and 18C136) }\end{array}$ & \\
\hline $\mathrm{Zp3}$ & GIIAGIIIKIKK & $4 \mu \mathrm{M}$ & $\begin{array}{l}\text { In vitro/ } \\
\text { In vivo }\end{array}$ & NR & $\begin{array}{l}\text { A. baumannii ATCC } \\
19606\end{array}$ & [60] \\
\hline $\begin{array}{l}\text { WWW } \\
\text { Symmetric } \\
\text { peptides }\end{array}$ & $\begin{array}{c}\text { XRWWWRX (XRW), } \\
\text { XWRWWWRWX (XWRW), } \\
\text { XRRWWWRRX (XRRW) } \\
\text { X=G, I, L, W, F, V, A }\end{array}$ & $\begin{array}{c}2->128 \\
\mu \mathrm{M}\end{array}$ & $\begin{array}{l}\text { In vitro/ } \\
\text { In vivo }\end{array}$ & NR & $\begin{array}{c}\text { E. coli ATCC 25922, P. } \\
\text { aeruginosa ATCC 27853/ } \\
\text { 9027, Acinetobacter } \\
\text { baumannii ATCC 19606, } \\
\text { K. pneumoniae ATCC } \\
\text { 700603, E. coli ML-35 } \\
\text { ATCC 43837, E. coli 780/ } \\
\text { 804, P. aeruginosa 50/ } \\
\text { 73, A. baumannii 9931/ } \\
\text { 97830 }\end{array}$ & [61] \\
\hline NR & $\begin{array}{c}\text { HKEMPFPK, TTMPLW, } \\
\text { YYQQKPVA, and AVPYPQR }\end{array}$ & $\begin{array}{l}1.5-5 \mathrm{mg} / \\
\mathrm{mL}\end{array}$ & In vitro & $\begin{array}{l}\text { Casein } \\
\text { prediction }\end{array}$ & $\begin{array}{c}\text { A. baumannii ATCC } \\
\text { 19606, E. coli O157 NCTC } \\
\text { 12900, P. aeruginosa PAO1 }\end{array}$ & [62] \\
\hline B1CTcu5 & LIAGLAANFLPQILCKIARKC & 12.5 & In vitro & $\begin{array}{l}\text { Clinotarsus } \\
\text { curtipes }\end{array}$ & M. tuberculosis & [56] \\
\hline \multirow{2}{*}{$\mathrm{Ctx}\left(\mathrm{Ile}^{21}\right)-\mathrm{Ha}$} & \multirow{2}{*}{ GWLDVAKKIGKAAFSVAKSFI } & \multirow{2}{*}{$64 \mu \mathrm{M}$} & \multirow{2}{*}{ In vitro } & \multirow{2}{*}{$\begin{array}{l}\text { Hypsiboas } \\
\text { albopunctatus }\end{array}$} & A. baumannii MDR & \multirow{2}{*}[5]{} \\
\hline & & & & & P. aeruginosa MDR & \\
\hline
\end{tabular}


Table 3. Cont.

\begin{tabular}{|c|c|c|c|c|c|c|}
\hline AMPs & Peptide Sequence & $\underset{(\mu \mathrm{g} / \mathrm{mL})}{\mathrm{MIC}}$ & System & Natural Source & $\begin{array}{c}\text { PDR/MDR/XDR } \\
\text { Bacteria }\end{array}$ & Ref. \\
\hline \multirow{3}{*}{$\begin{array}{l}\text { CDP-B11 } \\
\text { peptide }\end{array}$} & \multirow{3}{*}{$\begin{array}{l}\text { VRNSQSCRRNKGICV } \\
\text { PIRCPGSMRQIGTCL } \\
\text { GAQVKCCRRK }\end{array}$} & 25 & \multirow{5}{*}{ In vitro } & \multirow{3}{*}{ Cow } & A. baumannii \# 0035 & \multirow{3}{*}[63]{} \\
\hline & & 100 & & & E. coli \# 0061 & \\
\hline & & 200 & & & $\begin{array}{c}\text { E. coli \# 0346, P. } \\
\text { aeruginosa \# 0054 y K. } \\
\text { pneumoniae \# } 0347\end{array}$ & \\
\hline \multirow{2}{*}{$\begin{array}{l}\mathrm{P} 10+ \\
\text { conventional } \\
\text { antibiotics }\end{array}$} & \multirow{2}{*}{$\begin{array}{l}\text { LAREYKKIVEKLKR } \\
\text { WLRQVLRTLR }\end{array}$} & $4-32$ & & \multirow{2}{*}{$\begin{array}{l}\text { LL-37 } \\
\text { derivative }\end{array}$} & $\begin{array}{l}\text { A. baumannii XDR 1, } \\
\text { XDR 2, XDR 3, XDR 4, } \\
\text { XDR 5, ATCC } 19606 .\end{array}$ & \multirow{2}{*}{ [64] } \\
\hline & & $8-16$ & & & $\begin{array}{l}\text { P. aeruginosa colistin } \\
\text { resistant } 1,2,3,4,5 \text {, and } \\
\text { ATCC } 27853 \text {. }\end{array}$ & \\
\hline K11 & KWKSFIKKLTKKFLHSAKKF & NR & $\begin{array}{l}\text { In silico/ } \\
\text { In vitro }\end{array}$ & $\begin{array}{l}\text { Cecropin A1, } \\
\text { melittin, and } \\
\text { magainin }\end{array}$ & $\begin{array}{l}\text { A. baumannii, } P . \\
\text { aeruginosa, and } K . \\
\text { pneumoniae }\end{array}$ & {$[65]$} \\
\hline \multirow{10}{*}{$\begin{array}{l}\text { Magainin } 2 \\
\text { (Mag2) } \\
\text { (molecule and } \\
\text { homologues) }\end{array}$} & $\begin{array}{l}\text { GIGKFLHSAKKFGKAFVGE } \\
\text { IMNS }\end{array}$ & 12.5 & \multirow{10}{*}{ In vitro } & \multirow{10}{*}{$\begin{array}{l}\text { African clawed } \\
\text { frog }\end{array}$} & \multirow{10}{*}{ P. aeruginosa } & \multirow{10}{*}[66]{} \\
\hline & GIKKFLKSXKKFVKXFK & 3125 & & & & \\
\hline & S5IKKS5LKSAKKFVKAFK & 1.56 & & & & \\
\hline & GIKKS5LKSS5KKFVKAFK & 0.78 & & & & \\
\hline & GIKKFLKS5AKKS5VKAFK & 0.78 & & & & \\
\hline & GIKKFLKSS5KKFS5KAFK & 3125 & & & & \\
\hline & GIKKFLKSAKKS5VKAS5K & 0.78 & & & & \\
\hline & GIKKR8LKSAKKS5VKAFK & 1.56 & & & & \\
\hline & GIKKFLKR8AKKFVKS5FK & 3125 & & & & \\
\hline & GIKKFLKSR8KKFVKAS5K & 3125 & & & & \\
\hline \multirow{8}{*}{$\begin{array}{l}\text { Phe-Lys-Phe } \\
\text { tripeptide }\end{array}$} & \multirow{8}{*}{ FKF } & $>45.4 \mu \mathrm{M}$ & \multirow{7}{*}{ In vitro } & \multirow{8}{*}{ NR } & $\begin{array}{c}\text { K. pneumoniae ATCC } \\
13883\end{array}$ & \multirow{8}{*}[67]{} \\
\hline & & & & & $\begin{array}{c}\text { K. pneumoniae ATCC } \\
700603\end{array}$ & \\
\hline & & $45.4 \mu \mathrm{M}$ & & & E. coli ESBL 76 & \\
\hline & & $45.4 \mu \mathrm{IVI}$ & & & E. coli ESBL 63 & \\
\hline & & \multirow{3}{*}{$34.0 \mu \mathrm{M}$} & & & A. baumannii 5025055 & \\
\hline & & & & & P. aeruginosa 760111736 & \\
\hline & & & & & E. coli ATCC 25922 & \\
\hline & & NR & In vivo & & P. aeruginosa ATCC 27853 & \\
\hline Cec4 & $\begin{array}{c}\text { GWLKKIGKKIERVGQNTRD } \\
\text { ATIQAIGVAQQAAN- } \\
\text { VAATLKGK }\end{array}$ & 4 & In vitro & NR & $\begin{array}{l}200 \text { biofilm-forming } \\
\text { strains MDR and XDR of } \\
\text { P. aeruginosa (clinic } \\
\text { isolates) }\end{array}$ & {$[68,69]$} \\
\hline \multirow{3}{*}{ WLBU2 } & \multirow{3}{*}{$\begin{array}{l}\text { RRWVRRVRRWVRRV } \\
\text { VRVVRRWVRR }\end{array}$} & $1.5-3 \mu \mathrm{M}$ & \multirow{2}{*}{$\begin{array}{l}\text { In vivo/ } \\
\text { In vitro }\end{array}$} & \multirow{3}{*}{ eCAP modified } & $\begin{array}{c}24 \text { biofilm-forming } \\
\text { strains MDR and XDR of } \\
\text { A. baumannii }\end{array}$ & {$[70]$} \\
\hline & & 42,500 & & & $\begin{array}{l}\text { K. pneumoniae BAA-2146 } \\
\text { and } 700603\end{array}$ & \multirow{2}{*}{ [71] } \\
\hline & & 10,625 & In vitro & & A. baumannii BAA-1605 & \\
\hline \multirow{4}{*}{ BSI-9 analogs } & \multirow{4}{*}{ K-Nal-KK-Bip-O2Oc-Nal- } & $1-32$ & \multirow{4}{*}{ In vitro } & \multirow{4}{*}{ Cycllic peptide } & $\begin{array}{l}\text { S. aureus ATCC } 29213 \\
\text { (SA) }\end{array}$ & \\
\hline & & $2-32$ & & & P. aeruginosa ATCC 27853 & [721 \\
\hline & & $32 \rightarrow 64$ & & & E. coli ATCC 29522 & [72] \\
\hline & & & & & $\begin{array}{l}\text { A. baumannii ATCC } \\
19606\end{array}$ & \\
\hline
\end{tabular}


Table 3. Cont.

\begin{tabular}{|c|c|c|c|c|c|c|}
\hline AMPs & Peptide Sequence & $\underset{(\mu \mathrm{g} / \mathrm{mL})}{\mathrm{MIC}}$ & System & Natural Source & $\begin{array}{c}\mathrm{PDR} / \mathrm{MDR} / \mathrm{XDR} \\
\text { Bacteria }\end{array}$ & Ref. \\
\hline \multirow[b]{2}{*}{ TC19 } & \multirow[b]{2}{*}{ LRCMCIKWWSGKHPK } & \multirow[b]{2}{*}{$3.75 \mu \mathrm{M}$} & In vitro & \multirow{2}{*}{$\begin{array}{l}\text { Thrombocidin- } \\
\text { 1- human } \\
\text { peptide- } \\
\text { derived }\end{array}$} & E. coli ESBL & \multirow[b]{2}{*}{ [73] } \\
\hline & & & In vivo & & $\begin{array}{l}\text { A. baumannii LUH15100 } \\
\text { and S. aureus } \\
\text { JAR060131 }\end{array}$ & \\
\hline \multirow{9}{*}{$\begin{array}{l}\text { PepC/ } \\
\text { PepW }\end{array}$} & \multirow{9}{*}{$\begin{array}{c}\text { ILIACLGLKLLRYRRIY/ } \\
\text { WWWA\{Dab\}YGL\{Dab\}LL } \\
\text { \{Dab\}Y\{Dab\}\{Dab\}WY }\end{array}$} & $\begin{array}{l}8 \text { and } \\
1 \mu \mathrm{M}\end{array}$ & \multirow{9}{*}{$\begin{array}{l}\text { In vivo/ } \\
\text { In vitro }\end{array}$} & \multirow{9}{*}{ NR } & E. coli W3110 & \multirow{9}{*}{ [55] } \\
\hline & & $2 \mu \mathrm{M}$ & & & A. baumannii 5075 & \\
\hline & & $\begin{array}{l}2 \text { and } \\
1 \mu \mathrm{M}\end{array}$ & & & A. baumannii 17978 & \\
\hline & & \multirow{5}{*}{$\begin{array}{l}>128 \text { and } \\
\quad 2 \mu \mathrm{M}\end{array}$} & & & K. pneumoniae MKP103 & \\
\hline & & & & & K. pneumoniae ATCC 1705 & \\
\hline & & & & & $\begin{array}{l}\text { K. pneumoniae clinical } \\
\text { isolate } 1433\end{array}$ & \\
\hline & & & & & $\begin{array}{c}\text { K. pneumoniae clinical } \\
\text { isolate } 1434\end{array}$ & \\
\hline & & & & & $\begin{array}{l}\text { K. pneumoniae ATCC } \\
43816 \text { (K2 serotype/ } \\
\text { hypermucoviscous) }\end{array}$ & \\
\hline & & $\begin{array}{c}64 \text { and } \\
2 \mu \mathrm{M}\end{array}$ & & & $\begin{array}{l}\text { K. pneumoniae ATCC } \\
13883 \text { (K3 serotype) }\end{array}$ & \\
\hline$\underset{\beta \text {-defensin } 2}{\text { Human }}$ & $\begin{array}{l}\text { HBD2/ } \\
\text { L-HBD2 }\end{array}$ & $\begin{array}{l}0.25-0.5 \\
\mu \mathrm{M}\end{array}$ & \multirow[b]{2}{*}{ In vitro } & \multirow[b]{2}{*}{ Human } & $\begin{array}{l}\text { Pyorubin-producing } P \text {. } \\
\text { aeruginosa strain }\end{array}$ & \multirow[b]{2}{*}{ [74] } \\
\hline$\underset{\beta \text {-defensin } 3}{\text { Human }}$ & HBD3 & $1 \mu \mathrm{M}$ & & & & \\
\hline $\begin{array}{l}\text { Tridecaptin } \mathrm{M}+ \\
\quad \text { rifampicin }\end{array}$ & $\begin{array}{c}\mathrm{Gdab}^{*} \mathrm{GS}^{*} \mathrm{~W}^{*} \mathrm{SDabDab}{ }^{*} \mathrm{IQI} \alpha \mathrm{I}^{*} \mathrm{~S}- \\
\text { D-aminoacids}\end{array}$ & 16 & In vitro & $\begin{array}{l}\text { Paenibacillus sp. } \\
\text { M152 }\end{array}$ & A. baumannii ATCC 19606 & {$[75]$} \\
\hline \multirow{6}{*}{$\begin{array}{l}\text { Tilapia Piscidin } \\
\quad 4 \text { (TP4) }\end{array}$} & \multirow{6}{*}{$\begin{array}{l}\text { FIHHIIGGLFSAGKAI } \\
\text { HRLIRRRRR }\end{array}$} & 0.52 & \multirow{6}{*}{$\begin{array}{l}\text { In vivo/ } \\
\text { In vitro }\end{array}$} & \multirow{6}{*}{$\begin{array}{l}\text { Nile Tilapia } \\
\text { (Oreochromis } \\
\text { niloticus) }\end{array}$} & $\begin{array}{c}\text { P. aeruginosa (ATCC } \\
\text { 19660) }\end{array}$ & \multirow{6}{*}{ [76] } \\
\hline & & 3125 & & & K. pneumoniae (YT32) & \\
\hline & & \multirow{3}{*}{$<1.56$} & & & E. coli $(\mathrm{YT} 39)$ & \\
\hline & & & & & A. baumannii (Icu53) & \\
\hline & & & & & A. baumannii (Sk44) & \\
\hline & & 3127 & & & K. pneumoniae (NDM-1) & \\
\hline \multirow{4}{*}{ Oncocin } & \multirow{4}{*}{$\begin{array}{l}\text { VDKPPYLPRPRP } \\
\text { PRRIYNR }\end{array}$} & $8 \mu \mathrm{M}$ & \multirow{4}{*}{ In vitro } & \multirow{4}{*}{$\begin{array}{c}\text { Oncopeltus } \\
\text { fasciatus } \\
\text { (milkweed bug) }\end{array}$} & E. coli ATCC 25922 & \multirow{12}{*}{ [77] } \\
\hline & & $4 \mu \mathrm{M}$ & & & $\begin{array}{c}\text { K. pneumoniae ATCC } \\
10031\end{array}$ & \\
\hline & & $2 \mu \mathrm{M}$ & & & $\begin{array}{c}\text { K. pneumoniae CMCC } \\
46117\end{array}$ & \\
\hline & & $16 \mu \mathrm{M}$ & & & $\begin{array}{c}\text { E. coli ATCC } 25922 \\
(\Delta \text { SbmA })\end{array}$ & \\
\hline \multirow{4}{*}{ MDAP-2 } & \multirow{4}{*}{$\begin{array}{c}\text { SRDSRPVQPRVQPP } \\
\text { PPPKQKPSIYDTPIR } \\
\text { RPGGRKTMYA }\end{array}$} & $128 \mu \mathrm{M}$ & \multirow{4}{*}{ In vitro } & \multirow{4}{*}{$\begin{array}{l}\text { Musca domestica } \\
\text { larvae }\end{array}$} & E. coli ATCC 25922 & \\
\hline & & $512 \mu \mathrm{M}$ & & & $\begin{array}{l}\text { K. pneumoniae ATCC } \\
10031\end{array}$ & \\
\hline & & & & & $\begin{array}{l}\text { K. pneumoniae CMCC } \\
46117\end{array}$ & \\
\hline & & $256 \mu \mathrm{M}$ & & & $\begin{array}{c}\text { E. coli ATCC } 25922 \\
(\Delta \mathrm{SbmA})\end{array}$ & \\
\hline & & $1 \mu \mathrm{M}$ & & & E. coli ATCC 25922 & \\
\hline & & & & & $\begin{array}{l}\text { K. pneumoniae ATCC } \\
10031\end{array}$ & \\
\hline$\underset{\text { Oncocin })}{(\text { MDAP-2 }}+$ & VDKPPYLPRPR PIRRPGGR & $256 \mu \mathrm{M}$ & In vitro & hybrid & $\begin{array}{c}\text { K. pneumoniae CMCC } \\
46117\end{array}$ & \\
\hline & & & & & $\begin{array}{c}\text { E. coli ATCC } 25922 \\
(\triangle \mathrm{SbmA})\end{array}$ & \\
\hline
\end{tabular}


Table 3. Cont

\begin{tabular}{|c|c|c|c|c|c|c|}
\hline AMPs & Peptide Sequence & $\begin{array}{c}\mathrm{MIC} \\
(\mu \mathrm{g} / \mathrm{mL})\end{array}$ & System & Natural Source & $\begin{array}{c}\text { PDR/MDR/XDR } \\
\text { Bacteria }\end{array}$ & Ref. \\
\hline $\begin{array}{l}\text { Piscidin } 3 \\
\text { (g6498.t1) }\end{array}$ & $\begin{array}{l}\text { CIMKHLRNLWNGAK } \\
\text { AIYNGAKAGWTEFK }\end{array}$ & 45 & $\begin{array}{l}\text { In vivo/ } \\
\text { In vitro }\end{array}$ & \multirow{5}{*}{$\begin{array}{l}\text { Oreochromis } \\
\text { niloticus }\end{array}$} & P. aeruginosa & [78] \\
\hline \multirow{4}{*}{$\begin{array}{l}\text { Piscidin } 1 \\
\text { homologues }\end{array}$} & I9A-piscidin-1 & \multirow{4}{*}{3.1} & \multirow{4}{*}{ In vitro } & & \multirow{4}{*}{$\begin{array}{l}\text { Clinical strain of } \\
\text { colistin-resistant } A \text {. } \\
\text { baumannii }\end{array}$} & \multirow{4}{*}[79]{} \\
\hline & I16A-piscidin-1 & & & & & \\
\hline & I9K-piscidin-1 & & & & & \\
\hline & I16K-piscidin-1 & & & & & \\
\hline \multirow{4}{*}{ EcDBS1R6 } & \multirow{4}{*}{ PMKKLFKLLARIAVKIPVW } & $3 \mu \mathrm{M}$ & \multirow{4}{*}{$\begin{array}{l}\text { In vitro/ } \\
\text { In silico }\end{array}$} & \multirow{4}{*}{ NR } & E. coli ATCC 25922 & \multirow{4}{*}[80]{} \\
\hline & & $6.25 \mu \mathrm{M}$ & & & P. aeruginosa ATCC 27853 & \\
\hline & & $3 \mu \mathrm{M}$ & & & $\begin{array}{c}\text { K. pneumoniae ATCC } \\
13883\end{array}$ & \\
\hline & & $3 \mu \mathrm{M}$ & & & $\begin{array}{c}\text { A. baumannii ATCC } \\
19606\end{array}$ & \\
\hline $\begin{array}{l}\text { Iztli peptide } 1 \\
\text { (IP-1) }\end{array}$ & $\begin{array}{c}\text { KFLNRFWHWLQLKPG } \\
\text { QPMY }\end{array}$ & $\begin{array}{l}8 \mu \mathrm{g} / \\
100 \mu \mathrm{L}\end{array}$ & In vitro & NR & $\begin{array}{l}\text { M. tuberculosis H37Rv } \\
\text { (ATCC 27294) }\end{array}$ & [81] \\
\hline \multirow{5}{*}{$\begin{array}{c}\text { Buforin II + } \\
\text { monocar- } \\
\text { boxylic acid } \\
\text { derivative }\end{array}$} & \multirow{5}{*}{$\begin{array}{c}\text { TRSSRAGLQFPVGRVHR } \\
\text { LLRK }\end{array}$} & $1 \mu \mathrm{M}$ & \multirow{5}{*}{ In vitro } & \multirow{5}{*}{ NR } & E. coli (MG 1655) & \multirow{5}{*}[82]{} \\
\hline & & $2 \mu \mathrm{M}$ & & & P. aeruginosa (AR 0229) & \\
\hline & & $0.5 \mu \mathrm{M}$ & & & E. coli (AR 0114) & \\
\hline & & $0 .{ }^{2} \mu \mathrm{MV} 1$ & & & A. baumannii (Naval-17) & \\
\hline & & $4 \mu \mathrm{M}$ & & & K. pneumoniae (AR 0113) & \\
\hline \multirow{7}{*}{ CAMP-CecD } & \multirow{7}{*}{ RNFFKRIRRAGKRIRKAI } & 32 & \multirow{7}{*}{$\begin{array}{l}\text { In vitro/ } \\
\text { In silico }\end{array}$} & \multirow{7}{*}{$\begin{array}{l}\text { Cecropin } \\
\text { D-Derived from } \\
\text { insects }\end{array}$} & $\begin{array}{l}\text { K. pneumoniae } \\
\text { (wild-type KP) }\end{array}$ & \multirow{7}{*}{ [83] } \\
\hline & & 256 & & & K. pneumoniae (MDR-KP) & \\
\hline & & 128 & & & E. coli ATCC 25922 & \\
\hline & & 256 & & & K. pneumoniae (2146) & \\
\hline & & 64 & & & $\begin{array}{c}\text { P. aeruginosa } \\
\text { (wild-type PA) }\end{array}$ & \\
\hline & & 32 & & & P. aeruginosa (MDR-PA) & \\
\hline & & 32 & & & P. aeruginosa (27853) & \\
\hline \multirow{5}{*}{$\begin{array}{l}\text { SET-M33 } \\
\text { protease } \\
\text { resistant }\end{array}$} & \multirow{5}{*}{ (KKIRVRLSA)4K2KßA-OH } & \multirow{5}{*}{$0.7-3 \mu \mathrm{M}$} & \multirow{5}{*}{$\begin{array}{l}\text { In vivo/ } \\
\text { In vitro }\end{array}$} & \multirow{5}{*}{ NR } & $\begin{array}{c}\text { S. aureus (6 strains MDR/ } \\
\text { XDR) }\end{array}$ & \multirow{5}{*}{ [84] } \\
\hline & & & & & $\begin{array}{c}\text { P. aeruginosa (7 strains } \\
\text { MDR/ } \\
\text { XDR) }\end{array}$ & \\
\hline & & & & & $\begin{array}{l}\text { A. baumannii (3 strains } \\
\text { MDR/ } \\
\text { XDR) }\end{array}$ & \\
\hline & & & & & $\begin{array}{c}\text { E. coli (8 strains MDR/ } \\
\text { XDR) }\end{array}$ & \\
\hline & & & & & $\begin{array}{c}\text { K. pneumoniae (5 strains } \\
\text { MDR/ } \\
\text { XDR) }\end{array}$ & \\
\hline DP7 & \multirow[b]{2}{*}{ VQWRIRVAVIRK } & $16-32$ & & & $\begin{array}{l}\text { P. aeruginosa (MDR } \\
\text { various strains) }\end{array}$ & \\
\hline $\begin{array}{c}\text { DP7 + } \\
\text { vancomycin or } \\
\text { azithromycin }\end{array}$ & & NR & $\begin{array}{l}\text { In vitro/ } \\
\text { In silico }\end{array}$ & NR & $\begin{array}{l}\text { S. aureus, P. aeruginosa, } A \text {. } \\
\text { baumannii, and E. coli }\end{array}$ & [85] \\
\hline & & $16-32$ & & & P. aeruginosa & \\
\hline DP-C and DP-C & $\begin{array}{c}{[(\text { KLAKLAK)*2-L-C] }} \\
* \text { D-amino acids }\end{array}$ & $4-8$ & In vitro/ & NR & A. baumannii & [86] \\
\hline Dimer & (right-handed). & $4-16$ & In silico & IVIN & E. coli & {$[00]$} \\
\hline & & $16->128$ & & & K. pneumoniae & \\
\hline
\end{tabular}


Table 3. Cont.

\begin{tabular}{|c|c|c|c|c|c|c|}
\hline AMPs & Peptide Sequence & $\begin{array}{c}\text { MIC } \\
(\mu \mathrm{g} / \mathrm{mL})\end{array}$ & System & Natural Source & $\begin{array}{c}\text { PDR/MDR/XDR } \\
\text { Bacteria }\end{array}$ & Ref. \\
\hline \multirow[t]{3}{*}{$\Omega 76$ peptide } & \multirow[t]{3}{*}{ FLKAIKKFGKEFKKIGAKLK } & 16 & $\begin{array}{l}\text { In vivo/ } \\
\text { In vitro }\end{array}$ & \multirow[t]{3}{*}{ Mag derivative } & $\begin{array}{c}\text { carbapenem and } \\
\text { tigecycline-resistant } A \text {. } \\
\text { baumannii }\end{array}$ & \multirow[t]{3}{*}{ [87] } \\
\hline & & 128 & \multirow{2}{*}{ In vitro } & & K. pneumoniae & \\
\hline & & 4 & & & E. coli & \\
\hline \multirow{5}{*}{ NuriPep 1653} & \multirow{5}{*}{$\begin{array}{l}\text { VRGLAPKKSLWPF } \\
\text { GGPFKSPFN }\end{array}$} & 12 & \multirow{5}{*}{ In vitro } & \multirow{5}{*}{$\begin{array}{l}\text { P54 nutrient } \\
\text { reservoir } \\
\text { protein of } \\
\text { Pisum sativum }\end{array}$} & $\begin{array}{l}\text { A. baumannii-resistant } \\
\text { (ColRAB) PDR }\end{array}$ & \multirow{5}{*}{ [88] } \\
\hline & & 12 & & & $\begin{array}{l}\text { A. baumannii susceptible } \\
\text { (colSAB) }\end{array}$ & \\
\hline & & 400 & & & K. pneumoniae 50183 & \\
\hline & & 100 & & & E. coli ATCC 25922 & \\
\hline & & 8 & & & P. aeruginosa ATCC 27853 & \\
\hline \multirow{2}{*}{ Tachyplesin III } & \multirow{2}{*}{ KWCFRVCYRGICYRKCR } & \multirow{2}{*}{$10 \mathrm{mg} / \mathrm{kg}$} & \multirow{2}{*}{ In vivo } & \multirow{2}{*}{$\beta$-sheet AMP } & P. aeruginosa 1409 & \multirow{2}{*}{ [89] } \\
\hline & & & & & A. baumannii 1409 & \\
\hline Melittin & NR & 16 & $\begin{array}{l}\text { In vivo/ } \\
\text { In vitro }\end{array}$ & NR & $\begin{array}{l}\text { A. baumannii (XDR and } \\
\text { MDR strains, clinic } \\
\text { isolates) }\end{array}$ & [90] \\
\hline Protegrin-1 & RGGRLCYCRRRFCVCVGR & $4-8$ & In vitro & $\begin{array}{c}\beta \text {-sheet } \\
\text { peptides } \\
\text { (cathelicidin } \\
\text { family) }\end{array}$ & $\begin{array}{l}\text { A. baumannii (XDR and } \\
\text { MDR strains from } \\
\text { surgical wounds) }\end{array}$ & [91] \\
\hline Aurein 1.2 & GLFDIIKKIAESF-NH2 & 16 & \multirow{8}{*}{ In vitro } & \multirow{8}{*}{ NR } & \multirow{8}{*}{ A. baumannii ATCC 19606} & \multirow{8}{*}{ [92] } \\
\hline CAMEL & $\begin{array}{l}\text { KWKLFKKIGAVLKVL- } \\
\text { NH2 }\end{array}$ & 2 & & & & \\
\hline Citropin 1.1 & $\begin{array}{l}\text { GLFDVIKKVASVIGGL- } \\
\text { NH2 }\end{array}$ & 16 & & & & \\
\hline LL-37 & $\begin{array}{l}\text { LLGDFFRKSKEKIGKEFKRIV } \\
\text { QRIKDFLRNLVPRTES }\end{array}$ & 4 & & & & \\
\hline Omiganan & ILRWPWWPWRRK-NH2 & 32 & & & & \\
\hline r-Omiganan & KRRWPWWPWRLI-NH2 & 16 & & & & \\
\hline Pexiganan & $\begin{array}{l}\text { GIGKFLKKAKKFGKAFVKILKK } \\
\text { NH2 }\end{array}$ & K- & & & & \\
\hline Temporin A & FLPLIGRVLSGIL-NH2 & 128 & & & & \\
\hline \multirow{11}{*}{$\begin{array}{l}\text { Bac5(1-17) } \\
\text { native/ } \\
\text { Bac5- } \\
\text { derivatives }\end{array}$} & \multirow{11}{*}{$\begin{array}{c}\text { wt, 258, 272, 278, 281, and } \\
291 \text { peptides }\end{array}$} & \multirow{2}{*}{$2-16$} & \multirow{11}{*}{ In vitro } & \multirow{11}{*}{ NR } & E. coli BW25113 & \multirow{11}{*}{ [93] } \\
\hline & & & & & $\begin{array}{l}\text { E. coli C679-12 } \\
\text { EAEC:0104 }\end{array}$ & \\
\hline & & $4->64$ & & & $\begin{array}{l}\text { A. baumannii ATCC } \\
19606\end{array}$ & \\
\hline & & $1-16$ & & & $\begin{array}{l}\text { E. coli EURL-VTEC A07 } \\
\text { EPEC:O111 }\end{array}$ & \\
\hline & & & & & E. coli SSI-OO15 EIEC & \\
\hline & & \multirow{2}{*}{$1-2$} & & & E. coli SSI-NN14 ETEC & \\
\hline & & & & & E. coli EA22 ETEC & \\
\hline & & \multirow[t]{2}{*}{$16->64$} & & & $\begin{array}{l}\text { K. pneumoniae ATCC } \\
700603\end{array}$ & \\
\hline & & & & & P. aeruginosa ATCC 27853 & \\
\hline & & \multirow[t]{2}{*}{$8->64$} & & & $\begin{array}{l}\text { E. coli EURL-VTEC C07 } \\
\text { STEC:O157 }\end{array}$ & \\
\hline & & & & & E. coli BW25113 $\Delta \mathrm{sbmA}$ & \\
\hline SA4 peptide & IOWAGOLFOLFO-NH2 & & & & A. baumannii (MDR1, & \\
\hline SPO peptoid & $\begin{array}{l}\text { nInOnWnAnGnOnLnFnOn } \\
\text { LnFnO-NH2 }\end{array}$ & 50 & In vitro & NR & $\begin{array}{l}\text { MDR2, MDR3, and } \\
\text { MDR4) }\end{array}$ & [94] \\
\hline
\end{tabular}


Table 3. Cont.

\begin{tabular}{|c|c|c|c|c|c|c|}
\hline AMPs & Peptide Sequence & $\begin{array}{c}\mathrm{MIC} \\
(\mu \mathrm{g} / \mathrm{mL})\end{array}$ & System & Natural Source & $\begin{array}{c}\text { PDR/MDR/XDR } \\
\text { Bacteria }\end{array}$ & Ref. \\
\hline $\begin{array}{l}\text { D87(Lys1-6 } \\
\text { Arg-1) }\end{array}$ & \multirow{10}{*}{$\begin{array}{l}\text { Complex sequence (see } \\
\text { reference) }\end{array}$} & 0.8 & \multirow{10}{*}{ In vitro } & \multirow{10}{*}{ NR } & \multirow{10}{*}{$\begin{array}{l}7 \text { Strains of A. baumannii } \\
\text { resistant to Polymyxin B } \\
\text { and Colistin and } 20 \\
\text { Worldwide } 2016 \text { and } \\
\text { 2017 Isolates resistant to } \\
18 \text { Classical Antibiotics }\end{array}$} & \multirow{10}{*}{ [95] } \\
\hline $\begin{array}{l}\text { D84(Lys1-6 } \\
\text { Lys-1) }\end{array}$ & & $0.5-0.7$ & & & & \\
\hline $\begin{array}{l}\text { D85(Lys1-6 } \\
\text { Orn-1) }\end{array}$ & & 0.5 & & & & \\
\hline $\begin{array}{l}\text { D86(Lys1-6 } \\
\text { Dab-1) }\end{array}$ & & 1.0 & & & & \\
\hline $\begin{array}{l}\text { D105(Lys1-6 } \\
\text { Dap-1) }\end{array}$ & & $1-1.2$ & & & & \\
\hline $\begin{array}{c}\text { D101(Lys1Ser26- } \\
5 \\
\text { Lys-1) } \\
\end{array}$ & & $0.8-1$ & & & & \\
\hline $\begin{array}{c}\text { D102(Lys1Ser26- } \\
5 \\
\text { Dab-1) } \\
\end{array}$ & & $0.6-0.7$ & & & & \\
\hline $\begin{array}{c}\text { D85(K13A/ } \\
\text { K16A)-(Lys1-6 } \\
\text { Orn-1) }\end{array}$ & & $1.9-2$ & & & & \\
\hline $\begin{array}{l}\text { D86(K13A/ } \\
\text { K16A)-(Lys1-6 } \\
\text { Dab-1) }\end{array}$ & & 0.9 & & & & \\
\hline $\begin{array}{l}\text { D105(K13A/ } \\
\text { K16A)-(Lys1-6 } \\
\text { Dap-1) }\end{array}$ & & $1.3-2$ & & & & \\
\hline Agelaia-MPI & INWLKLGKAIIDAL & $\begin{array}{c}6.25-25 \\
\mu \mathrm{M}\end{array}$ & \multirow{5}{*}{ In vitro } & $\begin{array}{l}\text { Agelaia pallipes } \\
\text { pallipes }\end{array}$ & \multirow{5}{*}{$\begin{array}{l}\text { Clinical isolates of MDR } \\
\text { A. baumannii identified as } \\
\text { AB 02, AB 53, and AB } 72\end{array}$} & \multirow{5}{*}{ [96] } \\
\hline Polybia-MPII & INWLKLGKMVIDAL & $12.5-25$ & & $\begin{array}{c}\text { Pseudopolybia } \\
\text { vespiceps testacea }\end{array}$ & & \\
\hline Con10 & $\begin{array}{l}\text { FWSFLVKAASKILPS } \\
\text { LIGGGDDNKSSS }\end{array}$ & $\mu \mathrm{M}$ & & $\begin{array}{l}\text { Opisthacanthus } \\
\text { cayaporum }\end{array}$ & & \\
\hline NDBP-5.8 & GILGKIWEGVKSLI & \multirow{2}{*}{$>25 \mu \mathrm{M}$} & & $\begin{array}{l}\text { Opisthacanthus } \\
\text { cayaporum }\end{array}$ & & \\
\hline Polydim-I & $\begin{array}{l}\text { AVAGEKLWLLP } \\
\text { HLLKMLLTPTP }\end{array}$ & & & Polybia dimorpha & & \\
\hline ARV-1502 & $\begin{array}{c}\text { Chex-RPDKPRPTL } \\
\text { PRPRPPRPVR } \\
\end{array}$ & 50 & In vivo & Insect & $\begin{array}{l}\text { MDR A. baumannii Strain } \\
\text { HUMC1 }\end{array}$ & [97] \\
\hline \multirow{4}{*}{ Bac7(1-35) } & \multirow{4}{*}{ NR } & 4 & \multirow{4}{*}{ In vitro } & \multirow{4}{*}{ NR } & A. baumannii XDR 420 & \multirow{4}{*}{ [98] } \\
\hline & & 4 & & & A. baumannii MDR 7B & \\
\hline & & 2 & & & $\begin{array}{c}\text { A. baumannii MDR } \\
\text { AB5075 }\end{array}$ & \\
\hline & & & & & A. baumannii MDR 215B & \\
\hline $\begin{array}{c}\mathrm{P} 5+ \\
\text { meropenem }\end{array}$ & RIVQRIKKWLLKWKKLGY & 16 & In vitro & NR & P. aeruginosa M1351 & {$[50]$} \\
\hline PEP01 to PEP04 & $\begin{array}{c}\text { GKIMYILTKKS, } \\
\text { FGIKLRSVWKK, } \\
\text { FGIKLRSVWKR, and } \\
\text { FGIKLRKVWKD }\end{array}$ & $62.5-125$ & In silico & NR & K. pneumoniae МТСС619 & [99] \\
\hline NZX & $\begin{array}{c}\text { GFGCNGPWSEDDIQCHNH } \\
\text { CKSIKGYKGGYCARG } \\
\text { GFVCKCY } \\
\text { Disulfide bonds at position } \\
\text { C4-C30, C15-C37, C19-C39 }\end{array}$ & $\begin{array}{c}1.6-3.2 \\
\mu \mathrm{M}\end{array}$ & In vitro & $\begin{array}{l}\text { Plectasin } \\
\text { derivate }\end{array}$ & M. tuberculosis & [100] \\
\hline
\end{tabular}




\section{AMP Applications against High-Priority Bacteria}

This group includes the following bacteria: Enterococcus faecium, vancomycin-resistant; Staphylococcus aureus, methicillin-resistant, vancomycin intermediate, and resistant; Helicobacter pylori, clarithromycin-resistant; Campylobacter, fluoroquinolone-resistant; Salmonella spp., fluoroquinolone-resistant; Neisseria gonorrhoeae, third-generation cephalosporin-resistant, fluoroquinolone-resistant.

\subsection{Vancomycin-Resistant Enterococcus Faecium (VRE)}

Anoplin (GLLKRIKTLL-NH ${ }_{2}$ ) is a peptide isolated from the venom of the Japanese solitary spider wasp Anoplius samariensis. A study conducted by Munky et al. [101] evaluated the antimicrobial activity of Anoplin and its analogs. The AMP analogs were synthesized by substituting at $2,3,5,6,8,9$, and 10 amino acid positions. The synthesized analogs were peptides modified at position $5\left(\operatorname{Lys}^{5}\right.$ and $\left.\operatorname{Trp}^{5}\right)$, position $8\left(\mathrm{Lys}^{8}\right)$, positions 5 and 8 together $\left(\right.$ Lys $^{5} \mathrm{Lys}^{8}, \mathrm{Lys}^{5} \mathrm{Trp}^{8}, \operatorname{Trp}^{5} \mathrm{Lys}^{8}, \mathrm{Phe}^{5} \mathrm{Lys}^{8}$, and $\mathrm{Phe}^{5} \operatorname{Trp}^{8}$ ), $\beta$-2-naphthylalanine peptides $\left(2 \mathrm{Nal}^{2}, 2 \mathrm{Nal}^{3}, 2 \mathrm{Nal}^{6}, 2 \mathrm{Nal}^{9}\right.$, and $\left.2 \mathrm{Nal}^{10}\right)$, and $\beta$-cyclohexylalanine peptides $\left(\mathrm{Cha}^{2}{ }^{2}, \mathrm{Cha}^{3}\right.$, $\mathrm{Cha}^{6}, \mathrm{Cha}^{9}, \mathrm{Cha}^{10}$, and $\mathrm{Cha}^{2} \mathrm{Cha}^{10}$ ). The microdilution broth method was the technique used to determine antimicrobial assay against VRE (700 221), and the MICs values obtained for Anoplin and its 19 analogs varied from 0.8 to $170.6 \mu \mathrm{M}$. The positions 5- and 8-modified peptide, $\mathrm{Phe}^{5} \mathrm{Trp}^{8}$, showed the best MIC, $0.8 \mu \mathrm{M}$. This excellent activity is related to the increased hydrophobicity of the AMP and, consequently, the better interaction with the lipid membrane of bacteria. This study shows that small changes in peptide structure can alter the antimicrobial activity against certain bacteria.

The novel peptide BF2 was synthesized, purified, characterized, and biologically evaluated against clinical isolates of VRE by Singh et al. [102]. These authors analyzed the BF2 (RWRLLLLKKH) peptide against 2 ATCC strains (ATCC29212 and ATCC51299) and 26 clinical VRE isolates, clinical isolates from blood culture, wound swabs, the right abdomen, a hydrocathered tip, bile, and pus. The peptide showed antimicrobial activity against the standard strains with an MIC of $25 \mu \mathrm{g} / \mathrm{mL}$ and an MIC in the range of $6.25-12.5 \mu \mathrm{g} / \mathrm{mL}$ against the clinical isolates, which shows better activity against these strains. The hemolysis determined the cytotoxicity of BF2 peptide and showed that, up to $5 \mathrm{MIC}$, it was not hemolytic. They also performed a synergistic study between BF2 and the antibiotics (vancomycin, teicoplanin, and linezolid) against ATCC51299 and clinical isolates; and the results showed that vancomycin with BF2 has a synergistic effect with a fractional inhibitory concentration (FIC) index of 0.06-0.25, against ATCC and resistant strains, respectively. Simultaneously, BF2 with teicoplanin showed an FIC of $0.02-0.27$ for ATCC and clinical isolates. They observed no effect for the combination BF2/linezolid. An in vivo study was performed on Wistar albino female rats to verify the antimicrobial activity of the BF2 peptide studied by reducing the cell count in the blood of the animals. The inoculation of bacterial cells (VRE) was intravenous. One hour after administration, the animal groups were treated with 12.5 (MIC), 25 (2MIC), and $37.5 \mathrm{mg} / \mathrm{kg}$ (3MIC) of the peptide intravenously. After $1 \mathrm{~h}$ of treatment, the animals' blood was collected and plated for quantifying the number of bacterial cells. After a two-day therapy, reductions of $73 \%$, $76 \%$, and $82 \%$ were observed for the antimicrobial peptide treatments at MIC, $2 \mathrm{MIC}$, and $3 \mathrm{MIC}$ concentrations, respectively, in comparison with the negative control. In contrast, the positive control group, which received linezolid, had the number of colonies reduced by $93 \%$. BF2 is a peptide with good antimicrobial activity against vancomycin-resistant clinical isolates. It is nontoxic and effective in vivo, making it a promising antimicrobial to be studied both alone and in combination with antibiotics.

A cationic peptide composed of 22 amino acids, named Pexiganan or MSI 78, was evaluated in vitro against VRE strains by Flamm et al. [103]. The strains were isolated from diabetic foot infections, and the antimicrobial activity of pexiganan was evaluated by the broth microdilution testing method. The peptide showed good activity against VRE strains, with MIC values of 4 or $8 \mu \mathrm{g} / \mathrm{mL}$. The results showed that MSI 78 can be used as an antibiotic for VRE strains in diabetic patients. 
Delpech et al. [104] evaluated the peptide AP-CECT7121 alone and combined with gentamicin against five clinical isolates of VRE, ampicillin, and tetracycline. The five (DF02-043, DF04-056, DF02-065, DF03-072, and DF03-078)-resistant strains were isolated from mastitic cows. The bactericidal activity was determined by the agar dilution method, and it was observed that the peptide AP-CECT121 was able to kill the isolates, reducing viable cells by more than $4.0 \log _{10} \mathrm{CFU} / \mathrm{mL}$. However, a synergistic effect could not be observed when combined with gentamicin, as there was only a 0.2 to $0.9 \log _{10} \mathrm{CFU} / \mathrm{mL}$ reduction in viable cells. Therefore, AP-CEC7121 showed good activity alone and can be considered a candidate to treat bovine mastitis caused by VRE.

To evaluate synergistic effects, Wu et al. [105] performed a check-board study with the antimicrobial peptide P-113 and its derivatives against VRE. The following derivatives were developed with phenylalanine-(Phe-P-113), $\beta$-naphthylalanine-(Nal-P-113), $\beta$ diphenylalanine-(Dip-P-113), and $\beta-\left(4,4^{\prime}\right.$-biphenyl)alanine-(Bip-P-113)-substituted histidinerich antimicrobial peptide P-113 (Ac-AKRHHGYKRKFH-NH2). A clinically isolated strain of VRE (BCRC 15B0132) was purchased from Bioresources Collection \& Research Center (BCRC, FIRDI, Hsinchu, Taiwan). The antimicrobial activity assay was determined and vancomycin, P-113, and Phe-P-113 exhibited MIC $>64 \mu \mathrm{g} / \mathrm{mL}$ against E. faecium BCRC 15B0132, while the derivatives Bip-P-113, Dip-P-113, and Nal-P-113 showed an MIC equal to $4 \mu \mathrm{g} / \mathrm{mL}$. The synergic effect study was performed by combining vancomycin and peptides at the sub-inhibitory concentration (1/4 x MIC). The authors observed that Bip-P-113, Dip-P-113, and Nal-P-113 had a synergistic effect, and the other peptides showed no interaction. To evaluate the mechanism of resensitization of Enterococcus faecium to vancomycin by P-113 and its derivatives, the scientists experimented with BODIPY-labeled vancomycin. They noted that peptides with bulky unnatural amino acids increased vancomycin's entry into the VRE with the order Bip-P-113 = Nal-P-113 $>$ Dip-P-113 $>$ Phe-P-113 = P-113. This study shows that $\mathrm{P}-113$ derivatives can be used alone or in combination with vancomycin against VRE.

Wang et al. [106] discovered a new peptide, albopeptide, from the soil bacterium Streptomyces albofaciens (NCIMB 10975). After identifying this compound, the researchers synthesized its isomer and confirmed the peptide structure as L-Val-Dha-(E)-Dhb. With the low yield of the natural albopeptide for antibacterial activity against VRE, they used a 50:50 mixture of synthetic and natural peptide material for the experiment. The combination of peptides resulted in a potent activity against VRE K60-39, with a minimum inhibitory concentration (MIC) value of $2.98 \pm 0.07 \mu \mathrm{M}$.

\subsection{Clarithromycin-Resistant Helicobacter pylori}

Jiang et al. [107] studied the efficacy of the peptide Cbf-K16 (with 30 amino acids), in vitro and in vivo, against clarithromycin- and amoxicillin-resistant $H$. pylori SS1. An antimicrobial activity assay was carried out in vitro according to the microdilution technique, and the minimum inhibitory concentration (MIC) and minimum bactericidal concentration $(M B C)$ obtained were 16 and $32 \mu \mathrm{g} / \mathrm{mL}$, respectively. Cbf-K16 was also evaluated against H. pylori SS1-infected cells, GES-1 (gastric epithelial cells), and the compound reduced the bacterial count in the supernatant and intracellular samples to 1.9 and $2.9-\log _{10}$ units, respectively, in addition to protecting the epithelial cells. An antimicrobial activity assay in mice infected with drug-resistant $H$. pylori SS1 was performed with C57BL/ 6 male mice (4-6 weeks old). The animals received sodium bicarbonate by the intragastric route, and $0.3 \mathrm{~mL}\left(1 \times 10^{9} \mathrm{CFU} / \mathrm{mL}\right)$ of clarithromycin-resistant $H$. pylori SS1 on three alternate days for infection development. After infection, the mice were divided into different groups: the control group, triple therapy (omeprazole, clarithromycin, and amoxicillin), and peptide Cbf-K16 treatments at different doses $(5,10$, and $20 \mathrm{mg} / \mathrm{kg})$. The rats were treated daily for two weeks orally by the intragastric route, and $24 \mathrm{~h}$ after the last administration, they were euthanized, their blood was collected, and their stomachs were removed for analysis. Cbf-K16 at a dose of $20 \mathrm{mg} / \mathrm{kg}$ reduced the bacterial count in the stomach tissues of the animals to $3.9-\log _{10}$ units, in comparison with the control group. It also reduced the 
inflammation of the ulcer and gastric mucosa, as shown in the histological examination. By contrast, the triple therapy could not reduce the bacterial load of the resistant strain and had no action in gastritis. This study showed that $\mathrm{Cbf}-\mathrm{K} 16$ peptide has in vitro and in vivo activity against a strain of a clinical isolate of Clarithromycin-resistant $H$. pylori.

\subsection{Fluoroquinolone-Resistant Salmonella}

Szabo et al. [108] studied antimicrobial peptides (AMPs) that carry interaction domains with both the bacterial membrane and intracellular target and exhibit stability in the face of proteolytic degradation. The peptide AE-APO with the sequence (H-Chex-Arg-Pro-AspLysPro-Arg-Pro-Tyr-Leu-Pro-Arg-Pro-Arg-Pro-Pro-Arg-Pro-ValArg) ${ }_{2}-\mathrm{Dab}-\mathrm{NH}_{2}$ (where Chex is a 1-amino-cyclohexane carboxylic acid and Dab is 2,4-diamino-butyric acid) was analyzed in vitro against a clinical isolate of fluoroquinolone-resistant Salmonella enterica serovar Typhimurium. The in vitro efficacy was determined by conventional antibacterial growth inhibition assays [109], and the minimum inhibitory concentration (MIC) was 8-32 mg/L, that is, the peptide showed activity against the fluoroquinolone-resistant strain.

Cationic peptides LS-sarcotoxin and LS-stomoxyn were tested against a panel of 114 clinical MDR Gram-negative bacterial isolates, including fluoroquinolone-resistant Salmonella enterica. LS-sarcotoxin and LS-stomoxyn showed $\mathrm{MIC}_{50}$ and $\mathrm{MIC}_{90}$ values of 4 and $8 \mathrm{mg} / \mathrm{L}$, respectively, against clinical isolate $S$. enterica. The cytotoxicity activity of the peptides was determined by measuring intracellular ATP levels of HepG2 cells, and the authors observed no cytotoxic effect, only an $80 \%$ viability at concentrations of 420 and $433 \mathrm{mg} / \mathrm{L}$ for LS-sarcotoxin and LS-stomoxyn, respectively. In the hemolytic assay, for both peptides, the minimal hemolytic concentration determined for human erythrocytes was $1024 \mathrm{mg} / \mathrm{L}$, i.e., both showed no evidence of hemolytic activity. The in vivo tolerability assay was performed on healthy male Swiss mice. The animals received a single intravenous dose of $10 \mathrm{mg} / \mathrm{kg}$ of the respective peptides (LS-sarcotoxin and LSstomoxyn). They were evaluated daily for one month and no signs of toxicity were observed for either of the administered compounds. The pharmacokinetic profile of the peptides was determined in this study at $0.08,0.25,0.5,1,2,4,8$, and $24 \mathrm{~h}$ after administration of the $10 \mathrm{mg} / \mathrm{kg}$ dose of the respective compounds. Then, the $10 \mu \mathrm{L}$ blood sample was collected to quantify the peptide in plasma by tandem mass spectrometry (LC-MS), and the plasma concentrations above the lower limit of quantification (LLOQ) for LS-sarcotoxin and LS-stomoxyn were 1000 and $250 \mathrm{ng} / \mathrm{mL}$, at 5 and $15 \mathrm{~min}$ after administration, respectively. The peptides showed good antimicrobial activity against the resistant strain of S. enterica and no toxicity, and thus, they can be considered promising new antibiotics. However, they did not exhibit a good pharmacokinetic profile, which needs to be improved before in vivo efficacy assays can be performed [110].

\subsection{Staphylococcus aureus}

Various AMPs have shown potential against methicillin-resistant, vancomycin-resistant, and intermediate S. aureus (MRSA/VRSA/VISA), and most of the peptides against S. aureus were isolated from snake venom [111], bee venom [112], the skin of reptiles [113], and even from birds [114]. This is probably one of the most widely studied bacteria in recent decades of AMP applications.

A study that applied the combined action of melittin/mupirocin $(4.4$ and $14.22 \mu \mathrm{g} / \mathrm{mL})$ demonstrated the synergistic effect between the AMP-drug during treatment and highlighted its application as anti-biofilm formers against eight strains of MRSA [115]. This AMP is capable of inserting itself into the lipid membrane, forming a toroidal pore, and it also has an anti-VRE potential effect [116]. Likewise, WLBU2 is a promising peptide evaluated with $\mathrm{CPB}$ and $\mathrm{HPB}$, which showed activity even in the middle of the biofilm formed. These results allow us to have a base molecule, from which to generate new homologs that reduce its cytotoxicity to take it to the next experimental stage [117]. The previously described Bip-P-113 also showed promising activity against VISA, and thus, 
it created expectations about the synergy of peptidomimetics and AMPs [105]. For other high-priority bacterial strains, no AMP studies have been reported yet.

\section{Challenges and Perspectives}

Many AMPs, as demonstrated, have excellent properties against resistant bacteria. The difficulty in being applied to biological systems lies in the degradation and denaturation caused by biomolecules, such as proteolytic enzymes, and the gastric environment, as peptides and proteins can be hydrolyzed during their transport through the gastrointestinal tract when they are administered mainly orally [118]. This challenge has been deeply investigated through the use of protection and drug delivery technologies, such as micro and nanotechnology, with promising results for the development of new drugs [119,120].

Some AMPs present hemolytic activity, which is considered an important factor to be controlled and evaluated, as human cells could be lysed before the AMPs fulfill their objective [121]. However, some advances indicate that the manipulation of hydrophobicity could be crucial for this type of molecule, and for this reason, more studies of amino acid substitution within the peptide sequence must be carried out [56]. Furthermore, a previous study by our research group indicated that the use of microencapsulation with alginate by ionic gelation could decrease the hemolytic activity without affecting the antimicrobial activity of the $\mathrm{Ctx}\left(\mathrm{Ile}^{21}\right)$ peptide, making it useful as an oral food additive in formulations against MDR bacteria [5]. To the best of our knowledge, this is the first review article including AMPs against bacteria from the WHO priority list.

\section{Conclusions}

The progress of studies on AMPs against bacteria of critical and high priority according to the WHO has shown that the effectiveness of these peptides is, in certain cases, even better than that of conventional drugs. In addition, the combined use of AMP and drugs has a synergistic effect capable of reactivating the antimicrobial action of many obsolete drugs. The continuous study of AMPs in the pharmaceutical industry has produced promising results to solve the great problem of current bacterial resistance.

Author Contributions: Conceptualization, C.A.R.-B. and P.B.d.S.; investigation, C.A.R.-B., P.B.d.S., M.C.R., R.B.A., L.D.F., J.L.D., E.F.V.; writing—original draft preparation, C.A.R.-B.; writing-review and editing, C.A.R.-B., E.F.V. and F.R.P.; supervision, M.C., E.F.V. and F.R.P.; funding acquisition, F.R.P. All authors have read and agreed to the published version of the manuscript.

Funding: This study was supported by the São Paulo Research Foundation (FAPESP): Research Grant: 2020/13497-4 and Fellowships: 2018/25707-3 and 2020/16573-3. National Council for Scientific and Technological Development (CNPq): Research Grants: 429139/2018-7 and 404181/2019-8. Productivity Research Fellows (PQ CNPq): 303603/2018-6. This study was financed in part by the Coordenação de Aperfeiçoamento de Pessoal de Nível Superior-Brasil (CAPES)—Finance Code 001.

Institutional Review Board Statement: Not applicable.

Informed Consent Statement: Not applicable.

Data Availability Statement: Not applicable.

Conflicts of Interest: All contributing authors declare no conflict of interest.

\section{References}

1. Montalvo-Quirós, S.; Gómez-Graña, S.; Vallet-Regí, M.; Prados-Rosales, R.C.; González, B.; Luque-Garcia, J.L. Mesoporous silica nanoparticles containing silver as novel antimycobacterial agents against Mycobacterium tuberculosis. Colloids Surf. $B$ Biointerfaces 2021, 197, 111405. [CrossRef] [PubMed]

2. Perez, F.; Bonomo, R.A. Evidence to improve the treatment of infections caused by carbapenem-resistant Gram-negative bacteria. Lancet Infect. Dis. 2018, 18, 358-360. [CrossRef]

3. Riduan, S.N.; Armugam, A.; Zhang, Y. Antibiotic resistance mitigation: The development of alternative general strategies. J. Mater. Chem. B 2020, 8, 6317-6321. [CrossRef] 
4. Johnson, T.J.; Logue, C.M.; Johnson, J.R.; Kuskowski, M.A.; Sherwood, J.S.; Barnes, H.J.; Debroy, C.; Wannemuehler, Y.M.; Obata-Yasuoka, M.; Spanjaard, L.; et al. Associations between multidrug resistance, plasmid content, and virulence potential among extraintestinal pathogenic and commensal Escherichia coli from humans and poultry. Foodborne Pathog. Dis. 2012, 9, 37-46. [CrossRef]

5. Roque-Borda, C.A.; Silva, H.R.L.; Crusca Junior, E.; Serafim, J.A.; Meneguin, A.B.; Chorilli, M.; Macedo, W.C.; Teixeira, S.R.; Guastalli, E.A.L.; Soares, N.M.; et al. Alginate-based microparticles coated with HPMCP/AS cellulose-derivatives enable the Ctx(Ile21)-Ha antimicrobial peptide application as a feed additive. Int. J. Biol. Macromol. 2021, 183, 1236-1247. [CrossRef] [PubMed]

6. Bo, J.; Yang, Y.; Zheng, R.; Fang, C.; Jiang, Y.; Liu, J.; Chen, M.; Hong, F.; Bailey, C.; Segner, H.; et al. Antimicrobial activity and mechanisms of multiple antimicrobial peptides isolated from rockfish Sebastiscus marmoratus. Fish Shellfish Immunol. 2019, 93, 1007-1017. [CrossRef]

7. Abbas, A.; Lichtman, A.; Pillai, S. Cellular and Molecular Immunology, 8th ed.; Elsevier: Amsterdam, The Netherlands, 2014; ISBN 9780323316149.

8. Sierra, J.M.; Viñas, M. Future prospects for Antimicrobial peptide development: Peptidomimetics and antimicrobial combinations. Expert Opin. Drug Discov. 2021, 1-4. [CrossRef]

9. Kumar, T.V.V.; Sanil, G. A Review of the Mechanism of Action of Amphibian Antimicrobial Peptides Focusing on PeptideMembrane Interaction and Membrane Curvature. Curr. Protein Pept. Sci. 2017, 18, 1263-1272. [CrossRef]

10. Patocka, J.; Nepovimova, E.; Klimova, B.; Wu, Q.; Kuca, K. Antimicrobial Peptides: Amphibian Host Defense Peptides. Curr. Med. Chem. 2018, 26, 5924-5946. [CrossRef]

11. Magana, M.; Pushpanathan, M.; Santos, A.L.; Leanse, L.; Fernandez, M.; Ioannidis, A.; Giulianotti, M.A.; Apidianakis, Y.; Bradfute, S.; Ferguson, A.L.; et al. The value of antimicrobial peptides in the age of resistance. Lancet Infect. Dis. 2020, 20, e216-e230. [CrossRef]

12. Seyfi, R.; Kahaki, F.A.; Ebrahimi, T.; Montazersaheb, S.; Eyvazi, S.; Babaeipour, V.; Tarhriz, V. Antimicrobial Peptides (AMPs): Roles, Functions and Mechanism of Action. Int. J. Pept. Res. Ther. 2020, 26, 1451-1463. [CrossRef]

13. Nguyen, L.T.; Haney, E.F.; Vogel, H.J. The expanding scope of antimicrobial peptide structures and their modes of action. Trends Biotechnol. 2011, 29, 464-472. [CrossRef]

14. Mahlapuu, M.; Håkansson, J.; Ringstad, L.; Björn, C. Antimicrobial peptides: An emerging category of therapeutic agents. Front. Cell. Infect. Microbiol. 2016, 6, 194. [CrossRef]

15. Münzker, L.; Oddo, A.; Hansen, P.R. Chemical synthesis of antimicrobial peptides. In Methods in Molecular Biology; Humana Press Inc.: Totowa, NJ, USA, 2017; Volume 1548, pp. 35-49.

16. Bozelli, J.C.; Salay, L.C.; Arcisio-Miranda, M.; Procopio, J.; Riciluca, K.C.T.; Silva Junior, P.I.; Nakaie, C.R.; Schreier, S. A comparison of activity, toxicity, and conformation of tritrpticin and two TOAC-labeled analogues. Effects on the mechanism of action. Biochim. Biophys. Acta Biomembr. 2020, 1862, 183110. [CrossRef]

17. Vicente, E.F.; Sahu, I.D.; Costa-Filho, A.J.; Cilli, E.M.; Lorigan, G.A. Conformational changes of the Hs DHODH N-terminal Microdomain via DEER Spectroscopy. J. Phys. Chem. B 2015, 119, 8693-8697. [CrossRef] [PubMed]

18. Basso, L.G.M.; Mendes, L.F.S.; Costa-Filho, A.J. The two sides of a lipid-protein story. Biophys. Rev. 2016, 8, 179-191. [CrossRef] [PubMed]

19. Vicente, E.F.; Sahu, I.D.; Crusca, E.; Basso, L.G.M.; Munte, C.E.; Costa-Filho, A.J.; Lorigan, G.A.; Cilli, E.M. HsDHODH Microdomain-Membrane Interactions Influenced by the Lipid Composition. J. Phys. Chem. B 2017, 121, 11085-11095. [CrossRef] [PubMed]

20. Kang, H.-K.; Kim, C.; Ho Seo, C.; Park, Y. The therapeutic applications of antimicrobial peptides (AMPs): A patent review. J. Microbiol. 2017, 55, 1-12. [CrossRef]

21. WHO. Global Priority List of Antibiotic-Resistant Bacteria to Guide Research, Discovery, and Development of New Antibiotics; World Health Organization: Geneva, Switzerland, 2017.

22. Andrei, S.; Valeanu, L.; Chirvasuta, R.; Stefan, M.-G. New FDA approved antibacterial drugs: 2015-2017. Discoveries 2018, 6, e81. [CrossRef]

23. Andrei, S.; Droc, G.; Stefan, G. FDA approved antibacterial drugs: 2018-2019. Discoveries 2019, 7, e102. [CrossRef] [PubMed]

24. New Drugs at FDA: CDER's New Molecular Entities and New Therapeutic Biological Products IFDA. Available online: https:/ / www.fda.gov/drugs/development-approval-process-drugs/new-drugs-fda-cders-new-molecular-entities-and-newtherapeutic-biological-products (accessed on 7 May 2021).

25. Ullah, H.; Ali, S. Classification of Anti-Bacterial Agents and Their Functions. In Antibacterial Agents; InTech: London, UK, 2017; Volume 10.

26. Tacconelli, E.; Carrara, E.; Savoldi, A.; Harbarth, S.; Mendelson, M.; Monnet, D.L.; Pulcini, C.; Kahlmeter, G.; Kluytmans, J.; Carmeli, Y.; et al. Discovery, research, and development of new antibiotics: The WHO priority list of antibiotic-resistant bacteria and tuberculosis. Lancet Infect. Dis. 2018, 18, 318-327. [CrossRef]

27. Cardoso, P.; Glossop, H.; Meikle, T.G.; Aburto-Medina, A.; Conn, C.E.; Sarojini, V.; Valery, C. Molecular engineering of antimicrobial peptides: Microbial targets, peptide motifs and translation opportunities. Biophys. Rev. 2021, 13, 1-35. [CrossRef] [PubMed] 
28. Silva, T.B.; Monteiro, M.C.; Borges, R.D.; Barros, T.G.; Carneiro, A.D.; Barros, C.A. Theoretical and practical study of the cefoxitinEscherichia coli PBP5 complex interaction by molecular dynamics to obtain computational prototype of antimicrobial susceptibility to Gram negative bacteria. Chem. Biol. Drug Des. 2020, 96, 1095-1102. [CrossRef] [PubMed]

29. Evans, B.A.; Hamouda, A.; Amyes, G.B.S. The Rise of Carbapenem-Resistant Acinetobacter baumannii. Curr. Pharm. Des. 2013, 19, 223-238. [CrossRef]

30. El-Gamal, M.I.; Brahim, I.; Hisham, N.; Aladdin, R.; Mohammed, H.; Bahaaeldin, A. Recent updates of carbapenem antibiotics. Eur. J. Med. Chem. 2017, 131, 185-195. [CrossRef]

31. Bhowmick, T.; Weinstein, M.P. Microbiology of Meropenem-Vaborbactam: A Novel Carbapenem Beta-Lactamase Inhibitor Combination for Carbapenem-Resistant Enterobacterales Infections. Infect. Dis. Ther. 2020, 9, 757-767. [CrossRef] [PubMed]

32. Sims, M.; Mariyanovski, V.; McLeroth, P.; Akers, W.; Lee, Y.-C.; Brown, M.L.; Du, J.; Pedley, A.; Kartsonis, N.A.; Paschke, A. Prospective, randomized, double-blind, Phase 2 dose-ranging study comparing efficacy and safety of imipenem/cilastatin plus relebactam with imipenem/cilastatin alone in patients with complicated urinary tract infections. J. Antimicrob. Chemother. 2017, 72, 2616-2626. [CrossRef]

33. Kaye, K.; File, T.; Boucher, H.W.; Brown, M.; Aggrey, A.; Khan, I.; Joeng, H.-K.; Tipping, R.; Du, J.; Young, K.; et al. 1339. Results for the Supplemental Microbiological Modified Intent-to-Treat (SmMITT) Population of the RESTORE-IMI 1 Trial of Imipenem/Cilastatin/Relebactam (IMI/REL) vs. Imipenem/Cilastatin Plus Colistin (IMI+CST) in Patients with ImipenemNonsusceptible (NS) Bacterial Infections. Open Forum Infect. Dis. 2018, 5, S409. [CrossRef]

34. Newman, L.M.; Wang, S.A.; Ohye, R.G.; O'Connor, N.; Lee, M.V.; Weinstock, H.S. The epidemiology of fluoroquinolone-resistant Neisseria gonorrhoeae in Hawaii, 2001. Clin. Infect. Dis. 2004, 38, 649-654. [CrossRef]

35. Niero, G.; Bortolaia, V.; Vanni, M.; Intorre, L.; Guardabassi, L.; Piccirillo, A. High diversity of genes and plasmids encoding resistance to third-generation cephalosporins and quinolones in clinical Escherichia coli from commercial poultry flocks in Italy. Vet. Microbiol. 2018, 216, 93-98. [CrossRef]

36. Palma, N.; Pons, M.J.; Gomes, C.; Mateu, J.; Riveros, M.; García, W.; Jacobs, J.; García, C.; Ochoa, T.J.; Ruiz, J. Resistance to quinolones, cephalosporins and macrolides in Escherichia coli causing bacteraemia in Peruvian children. J. Glob. Antimicrob. Resist. 2017, 11, 28-33. [CrossRef] [PubMed]

37. Jacoby, G.A. Mechanisms of Resistance to Quinolones. Clin. Infect. Dis. 2005, 41, S120-S126. [CrossRef] [PubMed]

38. Kampshoff, F.; Willcox, M.D.P.; Dutta, D. A Pilot Study of the Synergy between Two Antimicrobial Peptides and Two Common Antibiotics. Antibiotics 2019, 8, 60. [CrossRef]

39. Blaskovich, M.A.T.; Hansford, K.A.; Butler, M.S.; Jia, Z.; Mark, A.E.; Cooper, M.A. Developments in Glycopeptide Antibiotics. ACS Infect. Dis. 2018, 4, 715-735. [CrossRef]

40. Santos-Beneit, F.; Ordóñez-Robles, M.; Martín, J.F. Glycopeptide resistance: Links with inorganic phosphate metabolism and cell envelope stress. Biochem. Pharmacol. 2017, 133, 74-85. [CrossRef] [PubMed]

41. Umstätter, F.; Domhan, C.; Hertlein, T.; Ohlsen, K.; Mühlberg, E.; Kleist, C.; Zimmermann, S.; Beijer, B.; Klika, K.D.; Haberkorn, U.; et al. Vancomycin Resistance Is Overcome by Conjugation of Polycationic Peptides. Angew. Chem. Int. Ed. 2020, 59, 8823-8827. [CrossRef]

42. Xuan, S.H.; Wu, L.P.; Zhou, Y.G.; Xiao, M.B. Detection of clarithromycin-resistant Helicobacter pylori in clinical specimens by molecular methods: A review. J. Glob. Antimicrob. Resist. 2016, 4, 35-41. [CrossRef]

43. Hirata, K.; Suzuki, H.; Nishizawa, T.; Tsugawa, H.; Muraoka, H.; Saito, Y.; Matsuzaki, J.; Hibi, T. Contribution of efflux pumps to clarithromycin resistance in Helicobacter pylori. J. Gastroenterol. Hepatol. 2010, 25, S75-S79. [CrossRef]

44. Narayana, J.L.; Huang, H.N.; Wu, C.J.; Chen, J.Y. Efficacy of the antimicrobial peptide TP4 against Helicobacter pylori infection: In vitro membrane perturbation via micellization and in vivo suppression of host immune responses in a mouse model. Oncotarget 2015, 6, 12936-12954. [CrossRef]

45. Elbehiry, A.; Marzouk, E.; Moussa, I.M.; Dawoud, T.M.; Mubarak, A.S.; Al-Sarar, D.; Alsubki, R.A.; Alhaji, J.H.; Hamada, M.; Abalkhail, A.; et al. Acinetobacter baumannii as a community foodborne pathogen: Peptide mass fingerprinting analysis, genotypic of biofilm formation and phenotypic pattern of antimicrobial resistance. Saudi J. Biol. Sci. 2021, 28, 1158-1166. [CrossRef]

46. Aygün, G.; Demirkiran, O.; Utku, T.; Mete, B.; Ürkmez, S.; Yilmaz, M.; Yaşar, H.; Dikmen, Y.; Öztürk, R. Environmental contamination during a carbapenem-resistant Acinetobacter baumannii outbreak in an intensive care unit. J. Hosp. Infect. 2002, 52, 259-262. [CrossRef] [PubMed]

47. Gehrlein, M.; Leying, H.; Cullmann, W.; Wendt, S.; Opferkuch, W. Imipenem Resistance in Acinetobacter baumanii Is Due to Altered Penicillin-Binding Proteins. Chemotherapy 1991, 37, 405-412. [CrossRef]

48. Vashist, J.; Tiwari, V.; Das, R.; Kapil, A.; Rajeswari, M.R. Analysis of penicillin-binding proteins (PBPs) in carbapenem resistant Acinetobacter baumannii. Indian J. Med. Res. 2011, 133, 332-338. [PubMed]

49. Mwangi, J.; Yin, Y.; Wang, G.; Yang, M.; Li, Y.; Zhang, Z.; Lai, R. The antimicrobial peptide ZY4 combats multidrugresistant Pseudomonas aeruginosa and Acinetobacter baumannii infection. Proc. Natl. Acad. Sci. USA 2019, 116, 26516-26522. [CrossRef] [PubMed]

50. Martinez, M.; Gonçalves, S.; Felício, M.R.; Maturana, P.; Santos, N.C.; Semorile, L.; Hollmann, A.; Maffía, P.C. Synergistic and antibiofilm activity of the antimicrobial peptide P5 against carbapenem-resistant Pseudomonas aeruginosa. Biochim. Biophys. Acta Biomembr. 2019, 1861, 1329-1337. [CrossRef] 
51. Bessa, L.J.; Eaton, P.; Dematei, A.; Plácido, A.; Vale, N.; Gomes, P.; Delerue-Matos, C.; SA Leite, J.R.; Gameiro, P. Synergistic and antibiofilm properties of ocellatin peptides against multidrug-resistant Pseudomonas aeruginosa. Future Microbiol. 2018, 13, 151-163. [CrossRef] [PubMed]

52. Grassi, L.; Maisetta, G.; Maccari, G.; Esin, S.; Batoni, G. Analogs of the Frog-skin Antimicrobial Peptide Temporin 1Tb Exhibit a Wider Spectrum of Activity and a Stronger Antibiofilm Potential as Compared to the Parental Peptide. Front. Chem. 2017, 5, 24 [CrossRef]

53. Eftekhar, F.; Naseh, Z. Extended-spectrum $\beta$-lactamase and carbapenemase production among burn and non-burn clinical isolates of Klebsiella pneumoniae. Iran. J. Microbiol. 2015, 7, 144-149.

54. Suay-García, B.; Pérez-Gracia, M.T. Present and future of carbapenem-resistant Enterobacteriaceae (CRE) infections. Antibiotics 2019, 8, 122. [CrossRef]

55. Fleeman, R.M.; Macias, L.A.; Brodbelt, J.S.; Davies, B.W. Defining principles that influence antimicrobial peptide activity against capsulated Klebsiella pneumoniae. Proc. Natl. Acad. Sci. USA 2020, 117, 27620-27626. [CrossRef] [PubMed]

56. Abraham, P.; Jose, L.; Maliekal, T.T.; Kumar, R.A.; Kumar, K.S. B1CTcu5: A frog-derived brevinin-1 peptide with anti-tuberculosis activity. Peptides 2020, 132, 170373. [CrossRef] [PubMed]

57. Maitra, A.; Nukala, S.; Dickman, R.; Martin, L.T.; Munshi, T.; Gupta, A.; Shepherd, A.J.; Arnvig, K.B.; Tabor, A.B.; Keep, N.H.; et al. Characterization of the MurT/GatD complex in Mycobacterium tuberculosis towards validating a novel anti-tubercular drug target. JAC-Antimicrob. Resist. 2021, 3, dlab028. [CrossRef]

58. Marin-Luevano, S.P.; Rodriguez-Carlos, A.; Jacobo-Delgado, Y.; Valdez-Miramontes, C.; Enciso-Moreno, J.A.; Rivas-Santiago, B. Steroid hormone modulates the production of cathelicidin and human $\beta$-defensins in lung epithelial cells and macrophages promoting Mycobacterium tuberculosis killing. Tuberculosis 2021, 128, 1472-9792. [CrossRef] [PubMed]

59. Orme, I. Search for new drugs for treatment of tuberculosis. Antimicrob. Agents Chemother. 2001, 45, 1943-1946. [PubMed]

60. Zeng, P.; Yi, L.; Xu, J.; Gao, W.; Xu, C.; Chen, S.; Chan, K.F.; Wong, K.Y. Investigation of antibiofilm activity, antibacterial activity, and mechanistic studies of an amphiphilic peptide against Acinetobacter baumannii. Biochim. Biophys. Acta Biomembr. 2021, 1863, 183600. [CrossRef]

61. Zhong, C.; Zhang, F.; Yao, J.; Zhu, Y.; Zhu, N.; Zhang, Y.; Liu, H.; Gou, S.; Ni, J. Antimicrobial peptides with symmetric structures against multidrug-resistant bacteria while alleviating antimicrobial resistance. Biochem. Pharmacol. 2021, 186, 114470. [CrossRef] [PubMed]

62. Um, J.; Manguy, J.; Anes, J.; Jacquier, J.C.; Hurley, D.; Dillon, E.T.; Wynne, K.; Fanning, S.; O'Sullivan, M.; Shields, D.C. Enriching antimicrobial peptides from milk hydrolysates using pectin/alginate food-gels. Food Chem. 2021, 352, 129220. [CrossRef]

63. Witherell, K.S.; Price, J.; Bandaranayake, A.D.; Olson, J.; Call, D.R. In vitro activity of antimicrobial peptide CDP-B11 alone and in combination with colistin against colistin-resistant and multidrug-resistant Escherichia coli. Sci. Rep. 2021, 11, 2151. [CrossRef] [PubMed]

64. Jahangiri, A.; Neshani, A.; Mirhosseini, S.A.; Ghazvini, K.; Zare, H.; Sedighian, H. Synergistic effect of two antimicrobial peptides, Nisin and P10 with conventional antibiotics against extensively drug-resistant Acinetobacter baumannii and colistin-resistant Pseudomonas aeruginosa isolates. Microb. Pathog. 2021, 150, 104700. [CrossRef]

65. Ramos-Martín, F.; Herrera-León, C.; Antonietti, V.; Sonnet, P.; Sarazin, C.; D’amelio, N. Antimicrobial peptide k11 selectively recognizes bacterial biomimetic membranes and acts by twisting their bilayers. Pharmaceuticals 2021, 14, 1. [CrossRef]

66. Hirano, M.; Saito, C.; Yokoo, H.; Goto, C.; Kawano, R.; Misawa, T.; Demizu, Y. Development of Antimicrobial Stapled Peptides Based on Magainin 2 Sequence. Molecules 2021, 26, 444. [CrossRef]

67. Azoulay, Z.; Aibinder, P.; Gancz, A.; Moran-Gilad, J.; Navon-Venezia, S.; Rapaport, H. Assembly of cationic and amphiphilic $\beta$-sheet FKF tripeptide confers antibacterial activity. Acta Biomater. 2021, 1968-1976. [CrossRef]

68. Liu, W.; Wu, Z.; Mao, C.; Guo, G.; Zeng, Z.; Fei, Y.; Wan, S.; Peng, J.; Wu, J. Antimicrobial Peptide Cec4 Eradicates the Bacteria of Clinical Carbapenem-Resistant Acinetobacter baumannii Biofilm. Front. Microbiol. 2020, 11, 1532. [CrossRef] [PubMed]

69. Peng, J.; Long, H.; Liu, W.; Wu, Z.; Wang, T.; Zeng, Z.; Guo, G.; Wu, J. Antibacterial mechanism of peptide Cec4 against Acinetobacter baumannii. Infect. Drug Resist. 2019, 12, 2417-2428. [CrossRef]

70. Di, Y.P.; Lin, Q.; Chen, C.; Montelaro, R.C.; Doi, Y.; Deslouches, B. Enhanced therapeutic index of an antimicrobial peptide in mice by increasing safety and activity against multidrug-resistant bacteria. Sci. Adv. 2020, 6, eaay6817. [CrossRef] [PubMed]

71. Swedan, S.; Shubair, Z.; Almaaytah, A. Synergism of cationic antimicrobial peptide WLBU2 with antibacterial agents against biofilms of multi-drug resistant Acinetobacter baumannii and Klebsiella pneumoniae. Infect. Drug Resist. 2019, 12, 2019-2030. [CrossRef] [PubMed]

72. Thomsen, T.; Mendel, H.; Al-Mansour, W.; Oddo, A.; Løbner-Olesen, A.; Hansen, P. Analogues of a Cyclic Antimicrobial Peptide with a Flexible Linker Show Promising Activity against Pseudomonas aeruginosa and Staphylococcus aureus. Antibiotics 2020, 9, 366. [CrossRef] [PubMed]

73. Riool, M.; de Breij, A.; Kwakman, P.H.S.; Schonkeren-Ravensbergen, E.; de Boer, L.; Cordfunke, R.A.; Malanovic, N.; Drijfhout, J.W.; Nibbering, P.H.; Zaat, S.A.J. Thrombocidin-1-derived antimicrobial peptide TC19 combats superficial multi-drug resistant bacterial wound infections. Biochim. Biophys. Acta Biomembr. 2020, 1862, 183282. [CrossRef]

74. Parducho, K.R.; Beadell, B.; Ybarra, T.K.; Bush, M.; Escalera, E.; Trejos, A.T.; Chieng, A.; Mendez, M.; Anderson, C.; Park, H.; et al The Antimicrobial Peptide Human Beta-Defensin 2 Inhibits Biofilm Production of Pseudomonas aeruginosa Without Compromising Metabolic Activity. Front. Immunol. 2020, 11, 805. [CrossRef] [PubMed] 
75. Jangra, M.; Raka, V.; Nandanwar, H. In Vitro Evaluation of Antimicrobial Peptide Tridecaptin M in Combination with Other Antibiotics against Multidrug Resistant Acinetobacter baumannii. Molecules 2020, 25, 3255. [CrossRef] [PubMed]

76. Hazam, P.K.; Chen, J.Y. Therapeutic utility of the antimicrobial peptide Tilapia Piscidin 4 (TP4). Aquac. Rep. 2020, 17, 100409. [CrossRef]

77. Liu, L.; Liu, J.; Cui, Q.; Jia, B.Y.; Pei, Z.H.; Odah, K.A.; Wang, Y.M.; Dong, W.L.; Kong, L.C.; Ma, H.X. Design and Characterization of a Novel Hybrid Antimicrobial Peptide OM19R Based on Oncocin and MDAP-2. Int. J. Pept. Res. Ther. 2020, 26, $1839-1846$. [CrossRef]

78. Tai, H.-M.; Huang, H.-N.; Tsai, T.-Y.; You, M.-F.; Wu, H.-Y.; Rajanbabu, V.; Chang, H.-Y.; Pan, C.-Y.; Chen, J.-Y. Dietary supplementation of recombinant antimicrobial peptide Epinephelus lanceolatus piscidin improves growth performance and immune response in Gallus gallus domesticus. PLoS ONE 2020, 15, e0230021. [CrossRef]

79. Taheri, B.; Mohammadi, M.; Momenzadeh, N.; Farshadzadeh, Z.; Roozbehani, M.; Dehghani, P.; Hajian, S.; Darvishi, S.; Shamseddin, J. Substitution of lysine for isoleucine at the center of the nonpolar face of the antimicrobial peptide, piscidin-1, leads to an increase in the rapidity of bactericidal activity and a reduction in toxicity. Infect. Drug Resist. 2019, 12, $1629-1647$. [CrossRef] [PubMed]

80. Porto, W.F.; Irazazabal, L.N.; Humblot, V.; Haney, E.F.; Ribeiro, S.M.; Hancock, R.E.W.; Ladram, A.; Franco, O.L. EcDBS1R6: A novel cationic antimicrobial peptide derived from a signal peptide sequence. Biochim. Biophys. Acta Gen. Subj. 2020, 1864, 129633. [CrossRef] [PubMed]

81. Peláez Coyotl, E.A.; Barrios Palacios, J.; Muciño, G.; Moreno-Blas, D.; Costas, M.; Montiel Montes, T.; Diener, C.; Uribe-Carvajal, S.; Massieu, L.; Castro-Obregón, S.; et al. Antimicrobial Peptide against Mycobacterium Tuberculosis That Activates Autophagy Is an Effective Treatment for Tuberculosis. Pharmaceutics 2020, 12, 1071. [CrossRef] [PubMed]

82. Pierce, S.; Jennings, M.P.; Juliano, S.A.; Angeles-Boza, A.M. Peptide-Ruthenium Conjugate as an Efficient Photosensitizer for the Inactivation of Multidrug-Resistant Bacteria. Inorg. Chem. 2020, 59, 14866-14870. [CrossRef]

83. Ocampo-Ibáñez, I.D.; Liscano, Y.; Rivera-Sánchez, S.P.; Oñate-Garzón, J.; Lugo-Guevara, A.D.; Flórez-Elvira, L.J.; Lesmes, M.C. A Novel Cecropin D-Derived Short Cationic Antimicrobial Peptide Exhibits Antibacterial Activity against Wild-Type and Multidrug-Resistant Strains of Klebsiella pneumoniae and Pseudomonas aeruginosa. Evol. Bioinform. 2020, 16, 117693432093626. [CrossRef]

84. Brunetti, J.; Carnicelli, V.; Ponzi, A.; Di Giulio, A.; Lizzi, A.R.; Cristiano, L.; Cresti, L.; Cappello, G.; Pollini, S.; Mosconi, L.; et al. Antibacterial and Anti-Inflammatory Activity of an Antimicrobial Peptide Synthesized with D Amino Acids. Antibiotics 2020, 9 , 840. [CrossRef]

85. Yin, Q.; Wu, S.; Wu, L.; Wang, Z.; Mu, Y.; Zhang, R.; Dong, C.; Zhou, B.; Zhao, B.; Zheng, J.; et al. A novel in silico antimicrobial peptide DP7 combats MDR Pseudomonas aeruginosa and related biofilm infections. J. Antimicrob. Chemother. 2020, 75, 3248-3259. [CrossRef]

86. Ohno, M.K.; Kirikae, T.; Yoshihara, E.; Kirikae, F.; Ishida, I. Addition of L-cysteine to the N- or C-terminus of the all-D-enantiomer [D(KLAKLAK)2] increases antimicrobial activities against multidrug-resistant Pseudomonas aeruginosa, Acinetobacter baumannii and Escherichia coli. Peer] 2020, 8, e10176. [CrossRef]

87. Nagarajan, D.; Roy, N.; Kulkarni, O.; Nanajkar, N.; Datey, A.; Ravichandran, S.; Thakur, C.; Sandeep, T.; Aprameya, I.V.; Sarma, S.P.; et al. W76: A designed antimicrobial peptide to combat carbapenem- And tigecycline-resistant Acinetobacter baumannii. Sci. Adv. 2019, 5, eaax1946. [CrossRef] [PubMed]

88. Mohan, N.M.; Zorgani, A.; Jalowicki, G.; Kerr, A.; Khaldi, N.; Martins, M. Unlocking NuriPep 1653 From Common Pea Protein: A Potent Antimicrobial Peptide to Tackle a Pan-Drug Resistant Acinetobacter baumannii. Front. Microbiol. 2019, 10, 2086. [CrossRef]

89. Qi, J.; Gao, R.; Liu, C.; Shan, B.; Gao, F.; He, J.; Yuan, M.; Xie, H.; Jin, S.; Ma, Y. Potential role of the antimicrobial peptide tachyplesin III against multidrug-resistant P. aeruginosa and A. baumannii coinfection in an animal model. Infect. Drug Resist. 2019, 12, 2865-2874. [CrossRef] [PubMed]

90. Pashaei, F.; Bevalian, P.; Akbari, R.; Pooshang Bagheri, K. Single dose eradication of extensively drug resistant Acinetobacter spp. In a mouse model of burn infection by melittin antimicrobial peptide. Microb. Pathog. 2019, 127, 60-69. [CrossRef]

91. Morroni, G.; Simonetti, O.; Brenciani, A.; Brescini, L.; Kamysz, W.; Kamysz, E.; Neubauer, D.; Caffarini, M.; Orciani, M.; Giovanetti, E.; et al. In vitro activity of Protegrin-1, alone and in combination with clinically useful antibiotics, against Acinetobacter baumannii strains isolated from surgical wounds. Med. Microbiol. Immunol. 2019, 208, 877-883. [CrossRef]

92. Jaśkiewicz, M.; Neubauer, D.; Kazor, K.; Bartoszewska, S.; Kamysz, W. Antimicrobial Activity of Selected Antimicrobial Peptides Against Planktonic Culture and Biofilm of Acinetobacter baumannii. Probiotics Antimicrob. Proteins 2019, 11, 317-324. [CrossRef]

93. Mardirossian, M.; Sola, R.; Beckert, B.; Collis, D.W.P.; Di Stasi, A.; Armas, F.; Hilpert, K.; Wilson, D.N.; Scocchi, M. Proline-Rich Peptides with Improved Antimicrobial Activity against E. coli, K. pneumoniae, and A. baumannii. ChemMedChem 2019, 14, 2025-2033. [CrossRef] [PubMed]

94. Sharma, D.; Choudhary, M.; Vashistt, J.; Shrivastava, R.; Bisht, G.S. Cationic antimicrobial peptide and its poly-N-substituted glycine congener: Antibacterial and antibiofilm potential against A. baumannii. Biochem. Biophys. Res. Commun. 2019, 518, 472-478. [CrossRef] [PubMed]

95. Mant, C.T.; Jiang, Z.; Gera, L.; Davis, T.; Nelson, K.L.; Bevers, S.; Hodges, R.S. De Novo Designed Amphipathic $\alpha$-Helical Antimicrobial Peptides Incorporating Dab and Dap Residues on the Polar Face to Treat the Gram-Negative Pathogen, Acinetobacter baumannii. J. Med. Chem. 2019, 62, 3354-3366. [CrossRef] [PubMed] 
96. das Neves, R.C.; Mortari, M.R.; Schwartz, E.F.; Kipnis, A.; Junqueira-Kipnis, A.P. Antimicrobial and Antibiofilm Effects of Peptides from Venom of Social Wasp and Scorpion on Multidrug-Resistant Acinetobacter baumannii. Toxins (Basel) 2019, 11, 216. [CrossRef] [PubMed]

97. Xiong, Y.Q.; Li, L.; Zhou, Y.; Kraus, C.N. Efficacy of ARV-1502, a Proline-Rich Antimicrobial Peptide, in a Murine Model of Bacteremia Caused by Multi-Drug Resistant (MDR) Acinetobacter baumannii. Molecules 2019, 24, 2820. [CrossRef] [PubMed]

98. Dolzani, L.; Milan, A.; Scocchi, M.; Lagatolla, C.; Bressan, R.; Benincasa, M. Sub-MIC effects of a proline-rich antibacterial peptide on clinical isolates of Acinetobacter baumannii. J. Med. Microbiol. 2019, 68, 1253-1265. [CrossRef]

99. Subramanian, D.; Chakkyarath, V.; Kumaravel, S.M.; Venkatesan, B.P.; Natarajan, J. Design, Synthesis and Evaluation of Antimicrobial Database-Derived Peptides Against Drug-Resistant Gram-Positive and Gram-Negative Pathogens. Int. J. Pept. Res. Ther. 2021, 1-10. [CrossRef]

100. Tenland, E.; Pochert, A.; Krishnan, N.; Umashankar Rao, K.; Kalsum, S.; Braun, K.; Glegola-Madejska, I.; Lerm, M.; Robertson, B.D.; Lindén, M.; et al. Effective delivery of the anti-mycobacterial peptide NZX in mesoporous silica nanoparticles. PLoS ONE 2019, 14, e0212858. [CrossRef]

101. Munk, J.K.; Uggerhøj, L.E.; Poulsen, T.J.; Frimodt-Møller, N.; Wimmer, R.; Nyberg, N.T.; Hansen, P.R. Synthetic analogs of anoplin show improved antimicrobial activities. J. Pept. Sci. 2013, 19, 669-675. [CrossRef]

102. Singh, K.; Kumar, S.; Shekhar, S.; Dhawan, B.; Dey, S. Synthesis and Biological Evaluation of Novel Peptide BF2 as an Antibacterial Agent against Clinical Isolates of Vancomycin-Resistant Enterococci. J. Med. Chem. 2014, 2, 1-6. [CrossRef] [PubMed]

103. Flamm, R.K.; Rhomberg, P.R.; Simpson, K.M.; Farrell, D.J.; Sader, H.S.; Jones, R.N. In Vitro Spectrum of Pexiganan Activity When Tested Against Pathogens from Diabetic Foot Infections and with Selected Resistance Mechanisms. Antimicrob. Agents Chemother. 2015, 59, 1751-1754. [CrossRef]

104. Delpech, G.; Bistoletti, M.; Ceci, M.; Lissarrague, S.; Bruni, S.S.; Sparo, M. Bactericidal Activity and Synergy Studies of PeptideAPCECT7121 Against Multi-resistant Bacteria Isolatedfrom Human and Animal Soft Tissue Infections. Probiotics Antimicrob. Prot. 2017, 9, 355-362. [CrossRef] [PubMed]

105. Wu, C.-L.; Hsueh, J.-Y.; Yip, B.-S.; Chih, Y.-H.; Peng, K.-L.; Cheng, J.-W. Antimicrobial Peptides Display Strong Synergy with Vancomycin Against Vancomycin-Resistant E. faecium, S. aureus, and Wild-Type E. coli. Int. J. Mol. Sci. 2020, 21, 4578. [CrossRef]

106. Wang, S.; Fang, Q.; Lu, Z.; Gao, Y.; Trembleau, L.; Ebel, R.; Andersen, J.H.; Philips, C.; Law, S.; Deng, H. Discovery and biosynthetic investigation of a new antibacterial dehydrated non-ribosomal tripeptide. Angew. Chem. Int. Ed. 2021, 60, 3229-3237. [CrossRef]

107. Jiang, M.; Mas, L.; Huang, Y.; Wu, H.; Dou, J.; Zhou, C. Antimicrobial activities of peptide Cbf-K16 against drug-resistant Helicobacter pylori infection in vitro and in vivo. Microb. Pathog. 2020, 138, 103847. [CrossRef] [PubMed]

108. Szabo, D.; Ostorhazi, E.; Binas, A.; Rozgonyi, F.; Kocsis, B.; Cassone, M.; Wade, J.D.; Nolte, O.; Otvos, L. The designer proline-rich antibacterial peptide A3-APO is effective against systemic Escherichia coli infections in different mouse models. Int. J. Antimicrob. Agents 2010, 35, 357-361. [CrossRef] [PubMed]

109. Sader, H.S.; Pignatari, A.C.C. E Test: A Novel Technique for Antimicrobial Suseptibility Testing. São Paulo Med. J. 1994, 112, 635-638. [CrossRef]

110. Hirsch, R.; Wiesner, J.; Marker, A.; Pfeifer, Y.; Bauer, A.; Hammann, P.E.; Vilcinksas, A. Profiling antimicrobial peptides from the medical maggot Lucilia sericata as potential antibiotics for MDR Gram-negative bacteria. J. Antimicrob. Chemother. 2019, 74, 96-107. [CrossRef] [PubMed]

111. Bocian, A.; Hus, K.K. Antibacterial properties of snake venom components. Chem. Pap. 2020, 74, 407-419. [CrossRef]

112. Choi, J.H.; Jang, A.Y.; Lin, S.; Lim, S.; Kim, D.; Park, K.; Han, S.M.; Yeo, J.H.; Seo, H.S. Melittin, a honeybee venom-derived antimicrobial peptide, may target methicillin-resistant Staphylococcus aureus. Mol. Med. Rep. 2015, 12, 6483-6490. [CrossRef]

113. Sang, Y.; Blecha, F. Antimicrobial peptides and bacteriocins: Alternatives to traditional antibiotics. Anim. Health Res. Rev. 2008, 9 , 227-235. [CrossRef] [PubMed]

114. Van Dijk, A.; Veldhuizen, E.J.A.; Haagsman, H.P. Avian defensins. Vet. Immunol. Immunopathol. 2008, 124, 1-18. [CrossRef]

115. Hakimi Alni, R.; Tavasoli, F.; Barati, A.; Shahrokhi Badarbani, S.; Salimi, Z.; Babaeekhou, L. Synergistic activity of melittin with mupirocin: A study against methicillin-resistant S. Aureus (MRSA) and methicillin-susceptible S. Aureus (MSSA) isolates. Saudi J. Biol. Sci. 2020, 27, 2580-2585. [CrossRef] [PubMed]

116. Al-Ani, I.; Zimmermann, S.; Reichling, J.; Wink, M. Pharmacological synergism of bee venom and melittin with antibiotics and plant secondary metabolites against multi-drug resistant microbial pathogens. Phytomedicine 2015, 22, 245-255. [CrossRef]

117. Elsalem, L.; Khasawneh, A.; Al Sheboul, S. WLBU2 Antimicrobial Peptide as a Potential Therapeutic for Treatment of Resistant Bacterial Infections. 2020. Available online: http:/ /cms.galenos.com.tr/Uploads/Article_42858/TJPS-0-0-En.pdf (accessed on 7 May 2021).

118. Meneguin, A.B.; Beyssac, E.; Garrait, G.; Hsein, H.; Cury, B.S.F. Retrograded starch/pectin coated gellan gum-microparticles for oral administration of insulin: A technological platform for protection against enzymatic degradation and improvement of intestinal permeability. Eur. J. Pharm. Biopharm. 2018, 123, 84-94. [CrossRef]

119. Roque Borda, C.A.; Saraiva de Mesquita Souza, M.; Monte, F.M.D.; Rodrigues Alves, L.B.; de Almeida, A.M.; Santiago Ferreira, T.; Spina de Lima, T.; Pereira Benevides, V.; Memrava Cabrera, J.; Meneguin, A.B.; et al. Application of HPMCAS-coated Ctx(Ile21)-Ha peptide microparticles as a potential use to prevent systemic infection caused by Salmonella Enteritidis in poultry. bioRxiv 2021. [CrossRef] 
120. Roque Borda, C.A.; Pereira, L.P.; Lopes Guastalli, E.A.; Soares, N.M.; Mac-Lean, P.A.B.; Salgado, D.D.; Meneguin, A.B.; Chorilli, M.; Vicente, E.F. HPMCP-coated microcapsules containing the Ctx(Ile 21 )-Ha antimicrobial peptide reduces the mortality rate caused by resistant Salmonella Enteritidis in poultry. bioRxiv 2021. [CrossRef]

121. Lei, J.; Sun, L.C.; Huang, S.; Zhu, C.; Li, P.; He, J.; Mackey, V.; Coy, D.H.; He, Q.Y. The antimicrobial peptides and their potential clinical applications. Am. J. Transl. Res. 2019, 11, 3919. [PubMed] 